Historic, Archive Document

Do not assume content reflects current scientific knowledge, policies, or practices. 



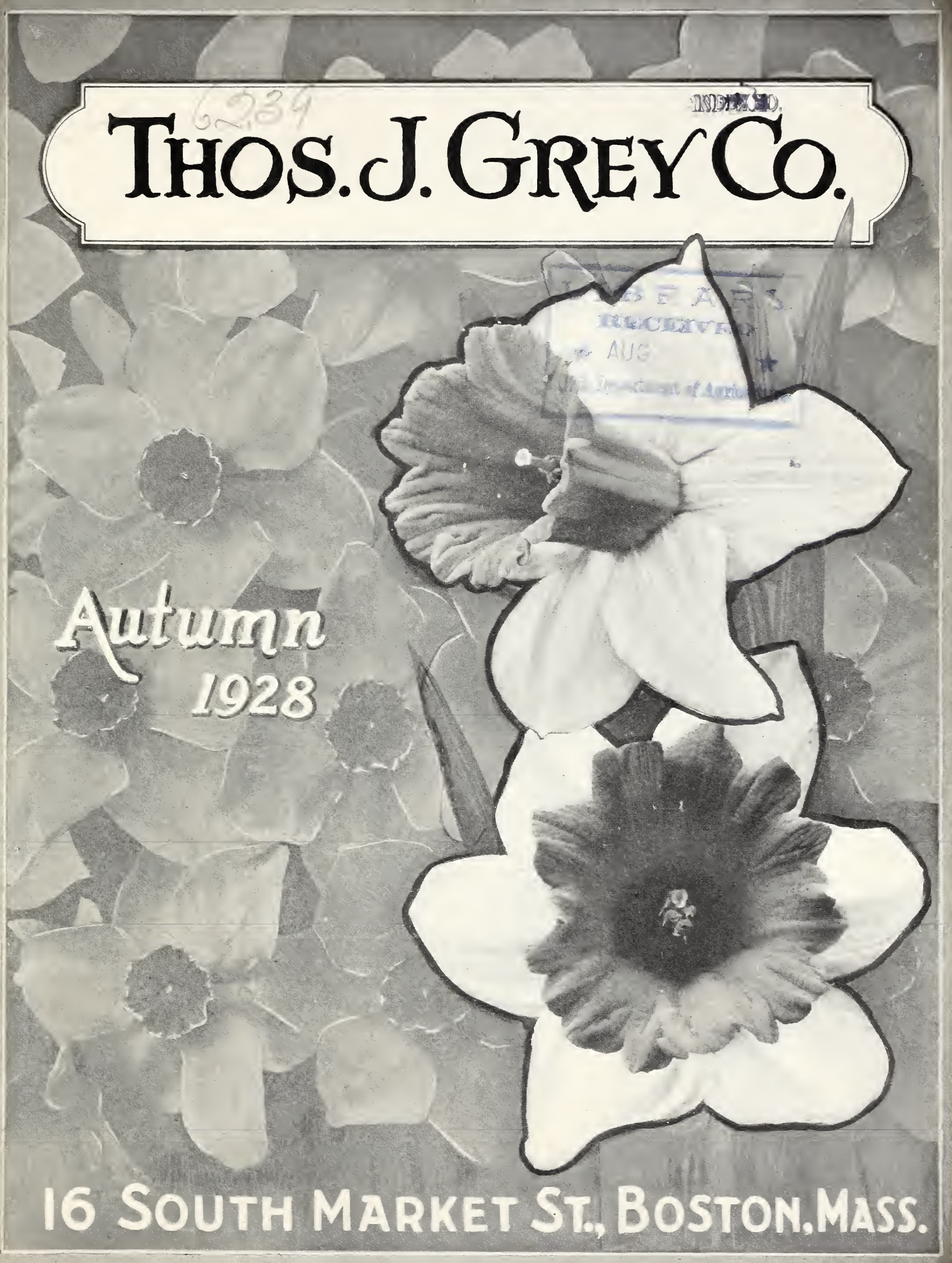




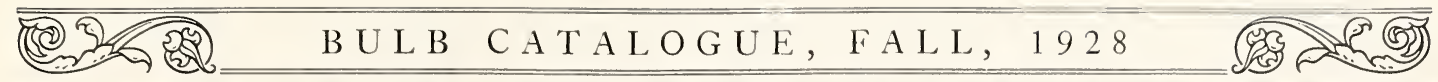

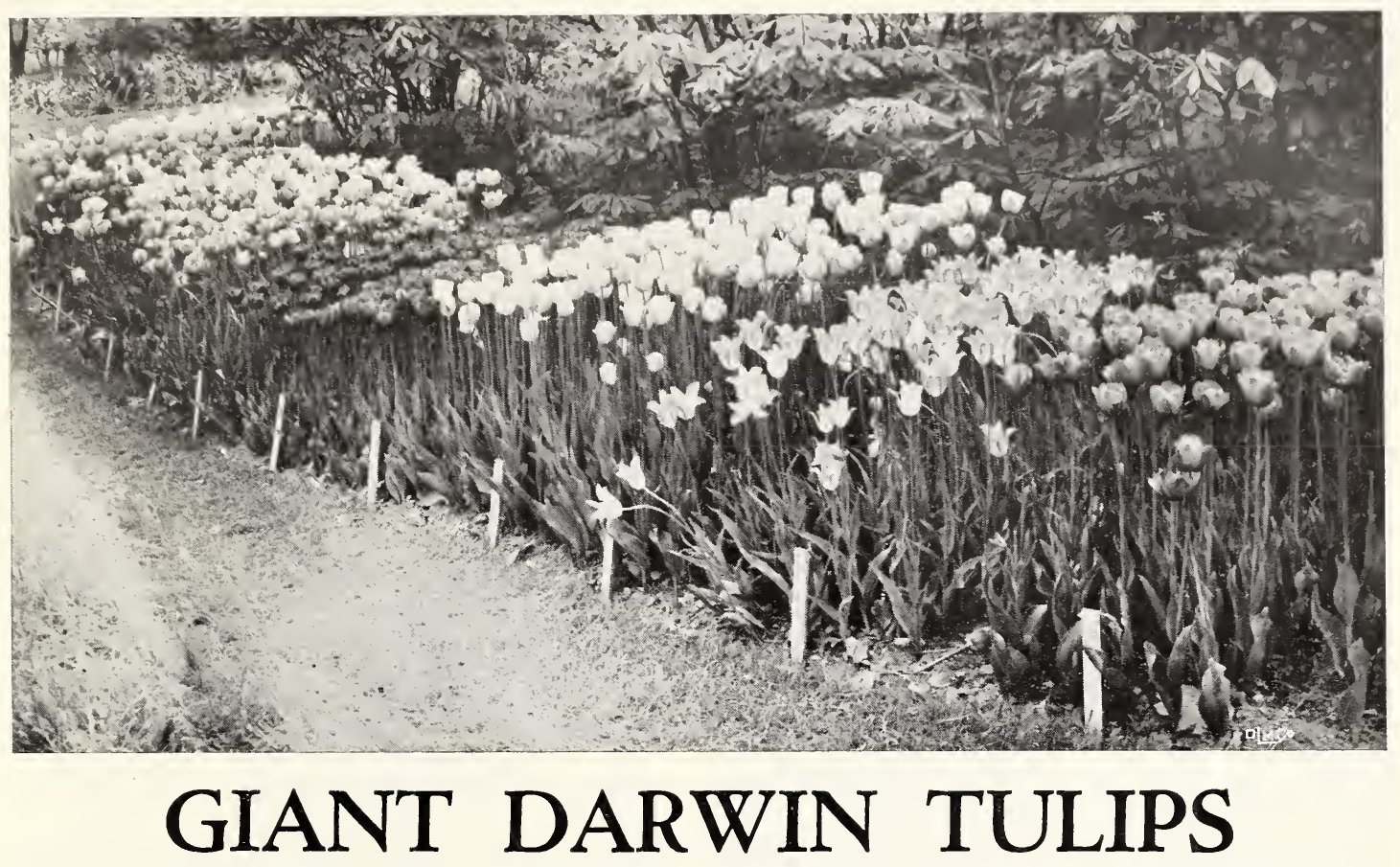

A distinct race of Single Late Tulips with immense flowers, of well-rounded form, on tall, thick stems from 2 to 3 feet in height. This, with their very brilliant colors, ranging from almost pure white through all the shades of pink and purple to the most intense red, makes them unsurpassed for planting out or for cutting. A bed of these tall Darwins, with an undergrowth of Myosotis, Daisies, etc., is a most beautiful sight; planted among the shrubbery, they give life and color to the garden. The varieties we offer are selected from a very large collection as the best and most distinct, containing none but the large flowering sorts. Forcing sorts marked with an asterisk $(*)$.

Mailed free at the dozen price, otherwise add postage at zone rates. Weight, 1 lb. per doz., $7 \mathrm{lbs}$. per 100.

\section{Single Late-Flowering}

*Afterglow. Deep rosy-orange with salmon-tinted edges, inside deep orange. Doz. $\$ 1.50,100 \$ 10.00$.

Ariadne. Brilliant crimson scarlet with violet center. Doz. T0c., $100 \$ 5.25,1000 \$ 50.00$.

Baronne de la Tonnaye. Vivid pink, with lighter margin; a faultless flower. Doz. 60c., $100 \$ 4.00$, $1000 \$ 38.00$.

*Bartigon. Fiery-red, excellent forcer. Doz. 70c., Bartigon. $100 \$ 4.50$.

Bleu Aimable. Soft bluish-lilac. Doz. 90c., 100

*Centenaire. Beautiful deep rose, flushed claret. 80c., $100 \$ 4.75$.

City of Haarlem. Immense vermilion scarlet, large Doz. $\$ 2.00,100 \$ 15.00$.

* Clara Butt. Beautiful soft salmon-pink; one of Che most popular. Doz. 55c., 100
*Europe (Salmon King). Glowing salmon-scarlet, white center; extra. Une of the most showy. Doz. $60 c ., 100 \$ 4.50,1000 \$ 42.00$

Farncombe Sanders. Very large; brilliant scarlet, 70c., $100 \$ 1.50,1000 \$ 12.00$.

Faust. Satiny-purple, with blue base; enormous 

Flamingo. Shell-pink, white center, pointed flower. Doz. 90c., $100 \$ 6.25$.

* Frans Hals. Large, bluish-violet. Highly recom$100 \$ 7.50$.

*Glow. Brilliant vermilion, blue and white center.

Glow. Doz. 70c., $100 \$ 5.00,1000 \$ 48.00$.

Harry Veitch. Brilliant blood-red, splendid bedder. Doz. 60c., $100 \$ 4.50$.

*Jeffries. Rose carmine, enormous flower. Excellent early forcer. Dos. \$1.00, $100 \$ 7.50$.

*Jubilee. Deep rich blue; egg-shaped. Doz. \$1.50, $100 \$ 12.00$. 


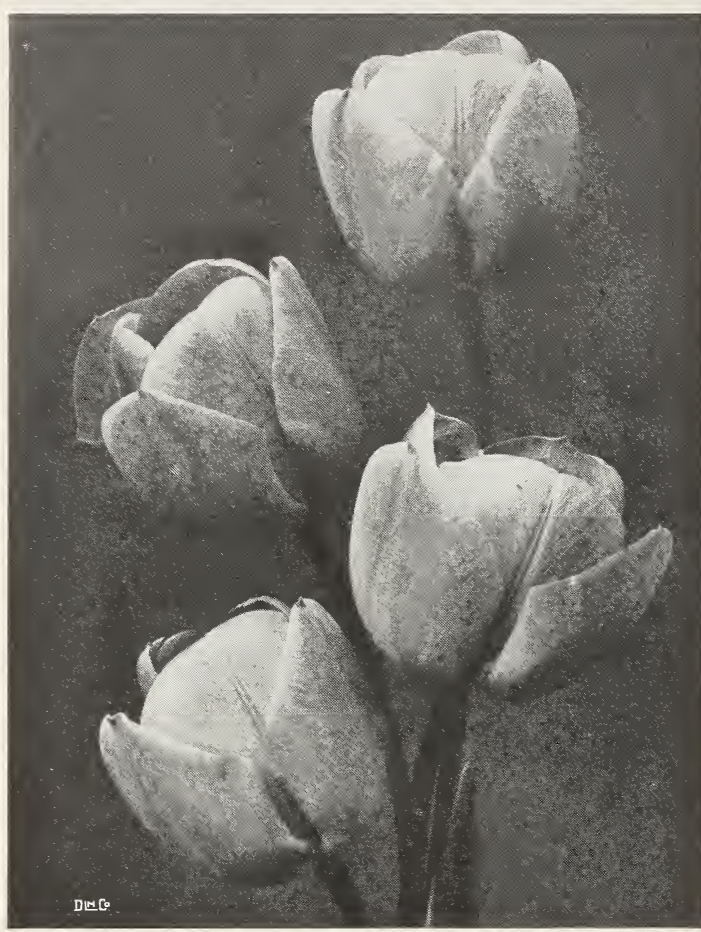

Rev. Ewbank

DARWIN TULIPS-Continucd

*King George V. Cherry-red; large and brilliant. Doz. $\$ 2.75,100 \$ 20.00$.

*King Harold. Dark maroon scarlet, splendid forcer. Doz. 60c., $100 \$ 4.50,1000 \$ 43.00$.

La Fiancee. One of the finest exhibition varieties. Rosy shaded mauve, edged light pink with blue base. Doz. $\$ 1.50,100 \$ 12.00$.

La Tulipe Noire. (The Black Tulip). VelvetyDoz. 90c., $100 \$ 6.25$.

*Loveliness. Soft carmine-rose, warm brilliant color. Doz. 60c., $100 \$ 4.50$.

* Madame Krelage. Bright rosy pink, lighter margin, large flower. Doz. 70c., $100 \$ 4.25,1000 \$ 36.00$.

Massachusetts. Vivid pink, white center, very large. Doz. 60c., $100 \$ 4.50,1000 \$ 43.00$.

Massenet. Apple blossom, flushed white with blueblack and white base. Doz. $\$ 1.20,100 \$ 9.00$.

* Petrus Hondius. Bright carmine-rose; extra large and showy. Doz. 85c., $100 \$ 6.00$.

* Pride of Haarlem. Old rose color, excellent for Putting. Doz. 60c., $100 \$ 4.00$, $1000 \$ 35.00$.

Prince of Netherlands. Deep cerise rose, margined pink, blue center. Doz. 85c., $100 \$ 6.00$.

* Princess Elizabeth. Soft lilac-rose on clear white base; excellent for forcing or border. Doz. 70c., $100 \$ 5.00$.

*Prof. Rauwenhoff. Bright cherry red, shaded salmon, enormous flower. Doz. 75c., $100 \$ 4.75$.

Page two
* Rev. Ewbank. Lavender-violet, shading to silver$1000 \$ 38.00$.

Remembrance. Mauve-heliotrope with deep silvery margin; very striking color. Doz. 60, $100 \$ 4.50$.

*Roi d'Islande. Deep violet-rose, excellent forcing

variety. Doz. \$1.10, $100 \$ 8.00$.

The Sultan. Velvety black maroon. Doz. 60c., $100 \$ 4.25$.

Valentine. Violet-purple, blue center. Doz. $\$ 1.00$, $100 \$ 7.00$.

White Queen. (La Candeur). Large, globular flower, open, rosy white and passes to pure white. Doz. 75c., $100 \$ 5.00$.

*Wm. Copland. (Sweet Lavender). Delicate lavender when forced; very early. Doz. 75c., $100 \$ 5.00,1000 \$ 48.00$.

*Wm. Pitt. Brilliant dark scarlet, excellent for pans. We. Doz. 85c., $100 \$ 6.00$.

Yellow Darwin. Clear canary-yellow. Doz. 70c., $100 \$ 4.50$.

*Zulu. Rich purplish-black. Doz. 75c., $100 \$ 5.00$.

\section{Darwin Tulips in Mixture}

Grey's Selected Mixture. Made up from the ties, thus giving the finest assortment of most barietiful colors. Doz. 90c., $100 \$ 6.50,1000 \$ 62.00$.

Superfine Mixture. A splendid mixture as imported. Doz. 45c., $100 \$ 3.25$, $1000 \$ 30.00$.

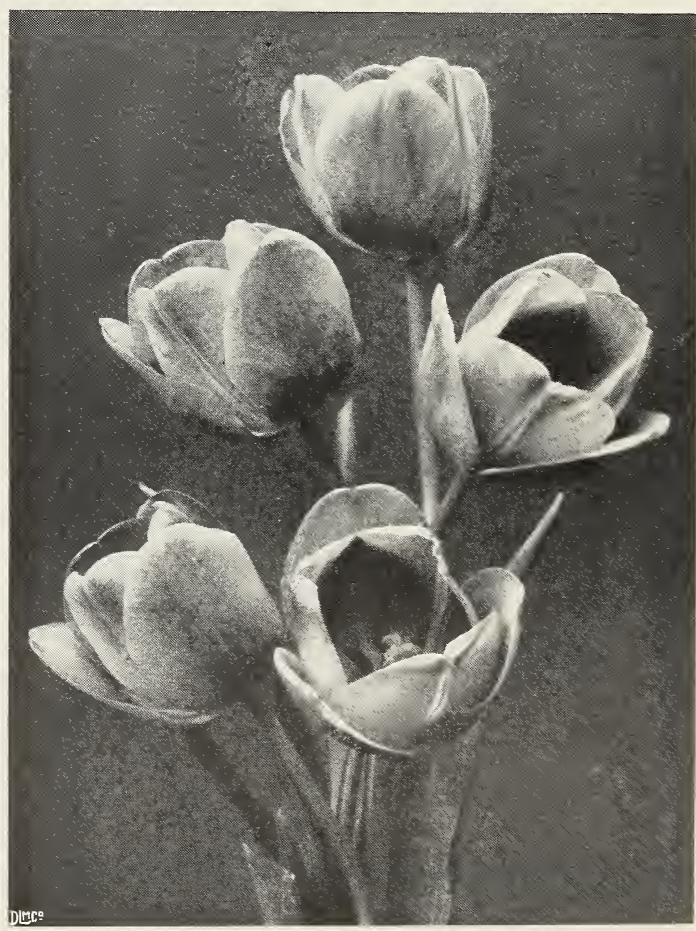

Clara Butt 


\section{TULIPS}

Universal favorites, and the most popular and attractive flowers for early Spring display in the garden or for Winter blooming in the house or conservatory. They are perfectly hardy and of easiest culture in any good garden soil, seldom failing to give the greatest satisfaction. When massed in beds or large clumps, the best effect is obtained Double and Single sorts, when planted together in clumps among the shrubs or perennials, give a longer season of bloom than if either were planted alone. For best effect, when planted

Mailed free at the dozen price, otherwise add postage at zone rates.

Weight 1 lb. per doz., i lbs. per 100.

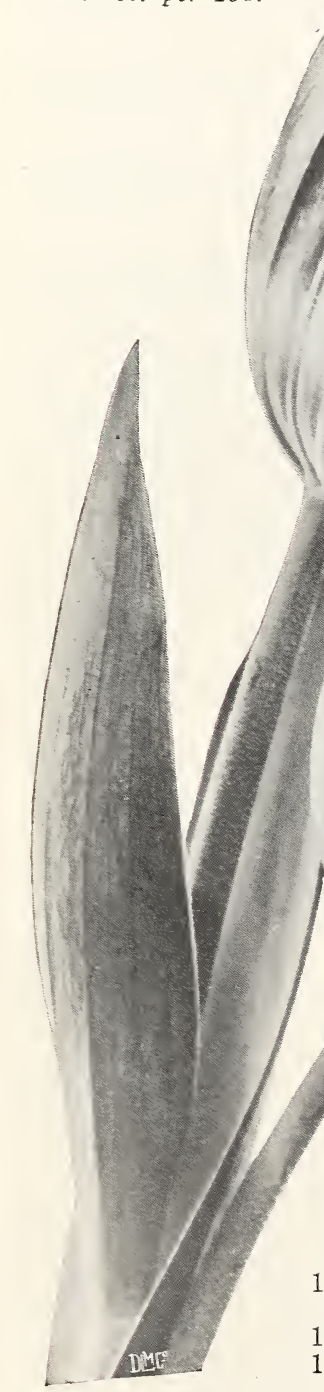

PRICES SUBJECT in small clumps, the bulbs should be set 4 inches deep and 4 inches apart, but in large beds or borders a distance of 5 or 6 inches between the bulbs can be allowed.

\section{Named Single Early Tulips}

Our collection embraces all the choicest varieties for forcing and bedding. The figures before the names indicate the height in inches, and the * the best sorts for forcing.

10 Artus. Brilliant scarlet; a splendid bedder. Doz. 5̌c., $100 \$ 3.75,1000 \$ 35.00$.

$10 *$ Belle Alliance. Large, sweet scented, scarlet flower; excellent. Doz. 80c., $100 \$ 5.75,1000 \$ 55.00$.

$10 *$ Cerise Grisdelin. Purple cerise, white bordered; very distinct. Doz. $\$ 1.00,100 \$ 7.00$.

11 Chrysolora. Large pure yellow, splendid bedder. Doz. 90c, $100 \$ 6.50,1000 \$ 62.00$.

$10 *$ Cottage Maid. Bright pink, fine for late forcing and excellent for bedding. Doz. 85c., $100 \$ 6.00$, $1000 \$ 55.00$.

$14 *$ Cramoisi Royal. Satiny carmine, tall flower, excellent forcing variety. Doz. $\$ 1.25$, $100 \$ 9.00$.

$12 *$ Cramoisi Brillant. Large crimson-scarlet; excellent for forcing or bedding. Doz. 60 c., $100 \$ 4.00,1000 \$ 38.00$. $12 *$ Duchess de Parma. Orange. red, margined deep yellow; tall, strong stem. Doz. 90c., $100 \$ 7.00,1000 \$ 65.00$.

11De Wet. Exhibition variety. scarlet. Doz. $\$ 1 . \overline{5} 5,100 \$ 12.00$

10*Dusart. Carmine-scarlet; very large, wide open flowers, excellent bedder. Doz. 75 c., $100 \$ 5.00,1000 \$ 48.00$.

12 Flamingo. Carmine rose over white, giving bright, deep pink effect; fine forcer. Doz. 80c. $100 \$ 5.50$.

Pink Beauty

$11 *$ Goldfinch. Rich, pure yellow; fragrant. An improved Yellow Prince. Doz. 90c., $100 \$ 6.75,1000 \$ 65.00$.

14*Grand Duc. (Keizerskroon). Brilliant red, with broad, yellow border Top roots. Doz. $\$ 1.10,100 \$ 8.00,1000 \$ 78.00$.

12 Joost Van den Vondel. Striped. Large, deep cherry red, feathered white. Doz. 85c., $100 \$ 6.00,1000 \$ 58.00$.

$12 *$ Lady Boreel. The largest and purest white, grand for exhibition or bedding. Doz. $90 \mathrm{c}, 100 \$ 6.50,1000 \$ 62.00$.

$12 *$ La Reve. Lovely, old rose shade, very large. Doz. 90c., $100 \$ 6.50$.

$12 *$ La Reine Maximus. An extra large-flowered La Reine, white, bordered rose. Doz. $75 \mathrm{c} ., 100 \$ 5.00,1000 \$ 48.00$. 


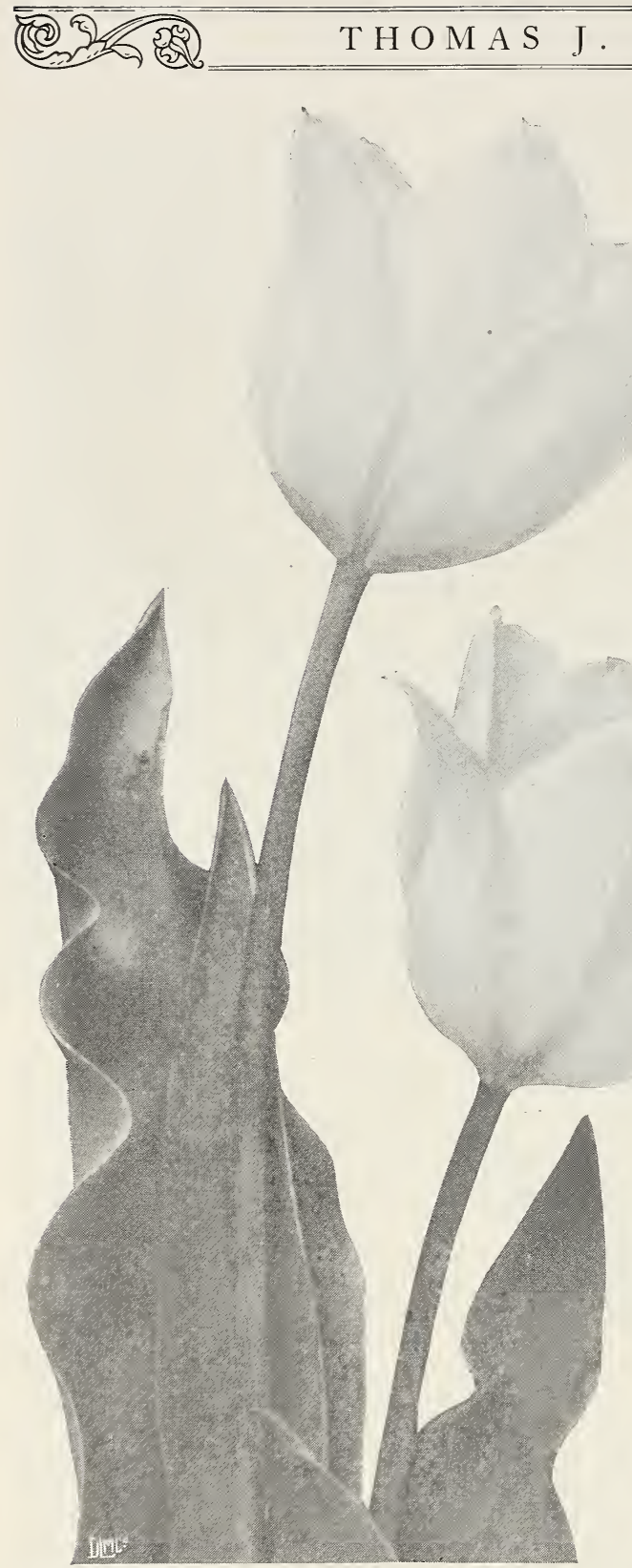

G R E Y C O M P A N Y

SINGLE EARLY TULIPS-Continued

14*Max Havelaar. Blood-orange, flushed salmon-rose. Doz. $\$ 1.10,100 \$ 8.00$.

12*Mon Tresor. Large; pure yellow; best Doz. $\$ 1.10,100 \$ 7.50$.

13 Pink Beauty. Large cherry-rose, center Doz. $\$ 2.00,100 \$ 14.00$.

$13 *$ Pink Delight. Deep rosy-pink, large flower of globular shape and very distinct. Doz. $\$ 4.00,100 \$ 30.00$.

11 *President Lincoln (Queen of Violets). Clear violet, with lighter edge. Doz. $\$ 1.10$, $100 \$ 7.50$.

$14 *$ Prince of Austria. Rich orange-red; fraDoz. 80c., $100 \$ 5.50$.

13 *Proserpine. Rich, satiny carmine-rose; very large and sweet-scented. Doz. $\$ 1.10$, $100 \$ 8.50$.

$13 *$ Queen of the Netherlands. Delicate, satiny pink; extra large and fine. Doz. 90c., $100 \$ 6.25$.

14 Queen of Pinks (Princess Wilhelmina). Deep pink, with white flush; large, pointed flowers. Doz. $\$ 1.00,100 \$ 7.00$.

14 Rising Sun. Deep golden yelDoz. $\$ 1.10,100 \$ 8.00$.

$11 *$ Rose Grisdelin. Delicate rose, flushed white; excellent forcer. Doz. 65c., 100 $\$ 4.50,1000 \$ 43.00$.

10* Rose Luisante. Dark, silky rose; beautiful and 80c., $100 \$ 6.50$.

$12 *$ Sir Thomas Lipton. Large, cup-shaped; brilliant scarlet. Doz. $\$ 1.10,100 \$ 7.75$.

14*Thomas Moore. Fine orange color; sweet-scented. Doz. 75 c., $100 \$ 5.00$.

$12 *$ Vermillon Brillant. Dazzling vermilion-scarlet; large and showy. Doz. 80c., $100 \$ 6.50$.

$12 *$ White Beauty. Large type. White sport of Pink Beauty, large pure white flower; exhibition variety. Doz. $\$ 2.00$, $100 \$ 14.00$.

14 White Hawk (Albion). Large; pure white; of great substance. Doz. 85c., $100 \$ 6.00,1000 \$ 55.00$.

12* Yellow Prince. Golden yellow, sweet-scented, popuelar forcing variety. Doz. 85c., 100 $\$ 6.50,1000 \$ 63.00$.

\section{SINGLE EARLY TULIPS IN MIXTURE}

Columbia Prize Mixture. Our specially blended mixture of decided merit, consisting of the finest largeflowering named sorts, selected to bloom at about the same time and to grow about the same height. This mixture is unsurpassed for mixed beds and borders. Doz. 75c., $100 \$ 5.00$, $1000 \$ 48.00$.

Superfine Mixture. A splendid mixture containing all colors, and composed of an unusually large number Page four of varieties which flower nearly together. Doz. 60c., $100 \$ 3.75,1000 \$ 35.00$. 


\section{NAMED DOUBLE TULIPS}

These are useful for bedding and forcing; the large, Peony-like blossoms are highly ornamental, coming into bloom about a week or more after the single early sorts, and lasting considerably longer in flower. They make the best display, and the effect is better when planted one variety in a bed or clump. 'The letter after the name indicates the time of blooming; those marked A bloom together, followed in about a week by $B$, and $\mathrm{C}$, the latest

Mailed free at the dozen price, otherwise add postage at zone rates. Weight, 1 lb. per doz., 7 lbs. per 100.

The figures before the names indicate the height in inches, and the $\left(^{*}\right)$ star indicates best sorts for forcing.

$11 *$ Boule de Neige. A. Large pure white, peonylike flower. Doz. 85c., $100 \$ 6.50$.

$11 *$ Grown of Gold. A. Golden yellow, flushed orange; large. Doz. 90c., $100 \$ 6.50$, $1000 \$ 62.00$.

$12 *$ Electra. Deep, warm carmine variety. Forces well. Doz. \$1.75, $100 \$ 12.00$.

$12 *$ Epicure. Old gold with orange yellow glow. enormous flower. Doz. $\$ 3.25$, $100 \$ 25.00$.

$12 *$ Le Matador. A. Glowing scarlet, splendid forcer and bedder. Doz. \$5c., 100 $\$ 6.50$.

$10 *$ Mr. Van der Hoeff. Pure yellow, sport of Murillo; recommendable new variety. Doz. $\$ 1.10,100 \$ 7.50$.

$10 *$ Murillo. B. Beautiful, light pink; excellent for pans. Doz. 70c., $100 \$ 4.50,1000$ $\$ 42.00$.

$11^{*}$ Peach Blossom. A sport of Murillo. Soft rosy-pink, and an excellent forcer. Doz. $\$ 1.10,100 \$ 7.50$.

$10 *$ Rubra Maxima. B. Large, deep crimson; fine forcer or bedder. Doz. 90c., $100 \$ 6.50$.

$12 *$ Schoonoord. B. Snow white; a sport of Murillo. Doz. 85̃c., $100 \$ 6.50$

$10^{*}$ Tea Rose (Saffrano). B. Soft saffron yellow Murillo, distinct shade. Doz. 75c., $100 \$ 5.50,1000 \$ 50.00$.

\section{Tulipa Clusiana}

This charming species is often called the Candystick Tulip or Lady Tulip. Fine for rockeries and for forcing in small pans. The foliage is very narrow, flowers elongated, bright cherry rose with white margins, conspicuous blue-black center. Never fails to draw admiration. Doz. 90c., $100 \$ 6.50$. 


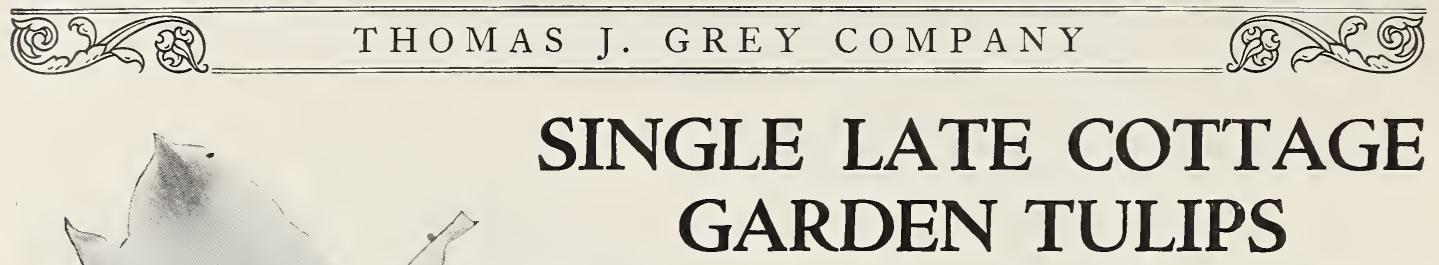

These beautiful May flowering varieties are becoming more popular each season, being entirely distinct from the early flowering sorts, in their taller growth and later season of blooming. 'The large, beautifully formed flowers of magnificent colors are usually at their best about Memorial Day, and last well into June.

Mailed free at the dozen price, otherwise add postage at zone rates. Weight, $1 \mathrm{lb}$. per doz., 7 lbs. per 100

Gesneriana Major (Spathulata). Large; rich crimsonscarlet, with blue cen ter. Doz. 75 c., $100 \$ 4.50$.

Gesneriana Lutea. Large, pure golden yellow; excellent for bedding. Doz. 60c., $100 \$ 4.00$, $1000 \$ 38.00$.

Golden Beauty (Ida). Pure golden yellow. Doz. 60c. $100 \$ 4.00$.

Grenadier. Brilliant orangered borne on very graceful stem. Do . 85c., $100 \$ 6.00$.

Inglescombe Pink (Salmon Queen). Delicate salmon-rose, immense flower. Doz. 60c., $100 \$ 4.00,1000 \$ 38.00$.

Inglescombe Yellow. Glossy canary-yellow; large, cupshape. Doz. 70c., $100 \$ 4.50$, $1000 \$ 42.00$.

John Ruskin. Salmon-rose, edged soft lemon-yellow. A beautiful combination of colors. Doz. 85 c., $100 \$ 5.50$.

La Candeur. Large, egg-shape, white, passing to rose. Doz. 75 c., $100 \$ 5.00$.

Moonlight. Pale straw, large oval-shaped flower of a soft, pleasing color. Doz. 85c., $100 \$ 5.50$.

Mrs. Moon. Deep, golden flower with reflexed, pointed petals. Doz. $\$ 1.10,100 \$ 7.50$.

Picotee (Maiden's Blush). White with rose-pink margin; flowers borne on long stems; splendid for forcing. Doz. 60c., 100 $\$ 4.25,1000 \$ 40.00$.

Splendid Mixture. Containing our selection of named varieties. Doz. 70c., 100 $\$ 4.50,1000 \$ 40.00$. 


\section{(3) DUTCH BREEDER TULIPS}

The Breeders are the unbroken forms of the old florist Tulips. A valuable Tulip for late flowering. They produce enormous flowers on long stems, colors running mostly in shades of bronze purple and brown. Bronze Queen. Buff, tinged apricot. Doz. 75c. $100 \$ 5.00$.

Cardinal Manning. Blend of mauve and rose. Doz. 90c., $100 \$ 6.50$.

Dom Pedro. A dull brown, shaded maroon, inside $100 \$ 11.00$.

Jaune d'Oeuf (Sunrise). Golden outside petals, shaded apricot. Doz. \$1.00, $100 \$ 7.00$.

Louis XIV. Purple flushed golden-bronze; globular flower. Doz. \$1.50, $100 \$ 10.00$.

Lucifer. Large reddish-orange; extra large flower. Dox. \$2.50, $100 \$ 18.00$.

Panorama. (Fairy). Large, deep orange-red. ExPancent forcer. Doz. \$1.00, $100 \$ \overline{6} .00$. Prince of Orange (Sunset). Terra cotta with $\$ 10.00$.

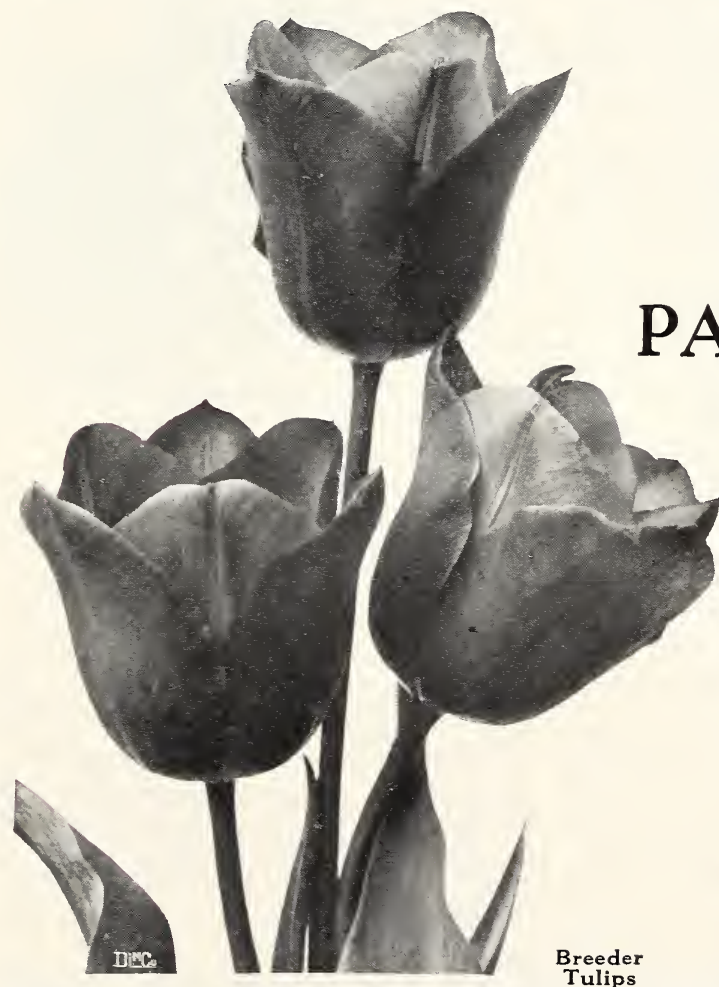

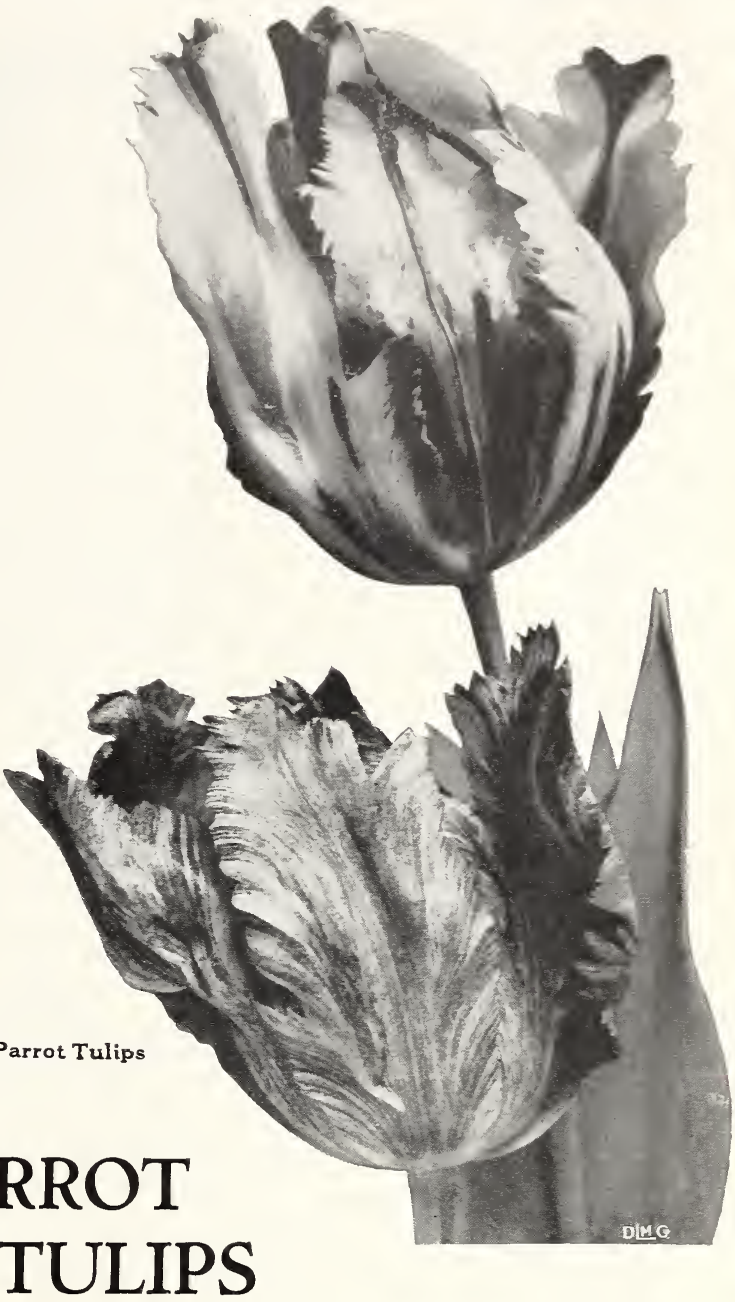

A singular and picturesque species of late flowering Tulips for outdoor cultivation, with peculiarly feathered and fringed petals. The flowers are of large size and very brilliant colors, combining shades peculiar to this species alone.

Admiral of Constantinople. Red, shaded orange. Doz. 85c., $100 \$ 6.00$.

Cafe Brun. Brown on yellow ground. Doz. 85c., $100 \$ 6.00$.

Cramoisi Brillant. Beautiful, large, brilliant crimson. Doz. 85 c., $100 \$ 6.00$.

Lutea Major. Bright yellow, feathered crimson and green. Doz. 85̃c., $100 \$ 6.00$.

Markgraaf. Brownish-red, feathered orange and purple. Doz. 85 c.. $100 \$ 6.00$.

Perfecta. Bright yellow, scarlet and green. Doz. 8j̃c., $100 \$ 6.00$.

Splendid Mixture. Doz. 80c., $100 \$ 5.50$. 


(4) THOMAS J. GREY COMPANY

\section{NARCISSI or DAFFODILS}

\section{AMERICAN GROWN}

Among the most beautiful and fragrant of our hardy Spring-flowering bulbs the Narcissi enjoy great popularity and occupy a very prominent place in the world of flowers, doing well in almost all soils and situations, for naturalizing among the grass, planting among the shrubbery, on the borders of ponds and streams, and in formal beds. For house or greenhouse culture they are equally desirable, planted in pots or bulb pans, several bulbs of one variety in each, and treated as recommended for Hyacinths. Selected bulbs only are offered and mostly Double Nosed.

If by Parcel Post, add postage at zone rates. Weight, 2 lbs. per doz., 15 lbs. per 100.

\section{Large Trumpet Narcissi}

Admiral Tromp. Large yellow trumpet with white perianth. Doz. $\$ 2.75,100 \$ 22.00$.

Christmas Glory. Early forcing variety, primrose trumpet; creamy perianth. Doz. $\$ 2.25,100 \$ 16.00$.

Emperor. Large, rich, golden yellow trumpet, deep primrose $100 \$ 18.0$ perianth. Selected Mother Bulbs. Doz. \$2.50,

Glory of Sassenheim. An enlarged bicolor Victoria. Fine for forcing and free flowering. Doz. $\$ 1.75,100 \$ 12.00$.

Golden Spur. Broad perianth and large trumpet, expanding at the lip; deep, golden yellow. Selected Mother Bulbs. Doz. $\$ 2.50$, $100 \$ 16.00$.

Herbert Smith. Sharply pointed, light vellow perianth, $100 \$ 22.00$.

King Alfred. Clear golden, with deeply frilled trumpet; un$100 \$ 28.00$.

Olympia. A splendid pot and forcing variety. Large vellow $\$ 2.75,100 \$ 22.00$.

Princeps maximus. Pale primrose perianth and large, deep yellow trumpet. Doz. $\$ 1.50,100 \$ 10.00$.

Robert Sydenham. Exhibition variety. Large yellow trum$100 \$ 35.00$.

Sir Francis Drake. Clear yellow, long-stemmed cut flower $\$ 3.50,100 \$ 25.00$.

Van Waveren's Giant. An enormous flower. Bright yellow 40c., doz. \$4.00, $100 \$ 30.09$.

Vanilla. Pale yellow perianth. Long narrow trumpet. Flowers

Vanilla. Pale yellow perianth. Long narrow trumpet.

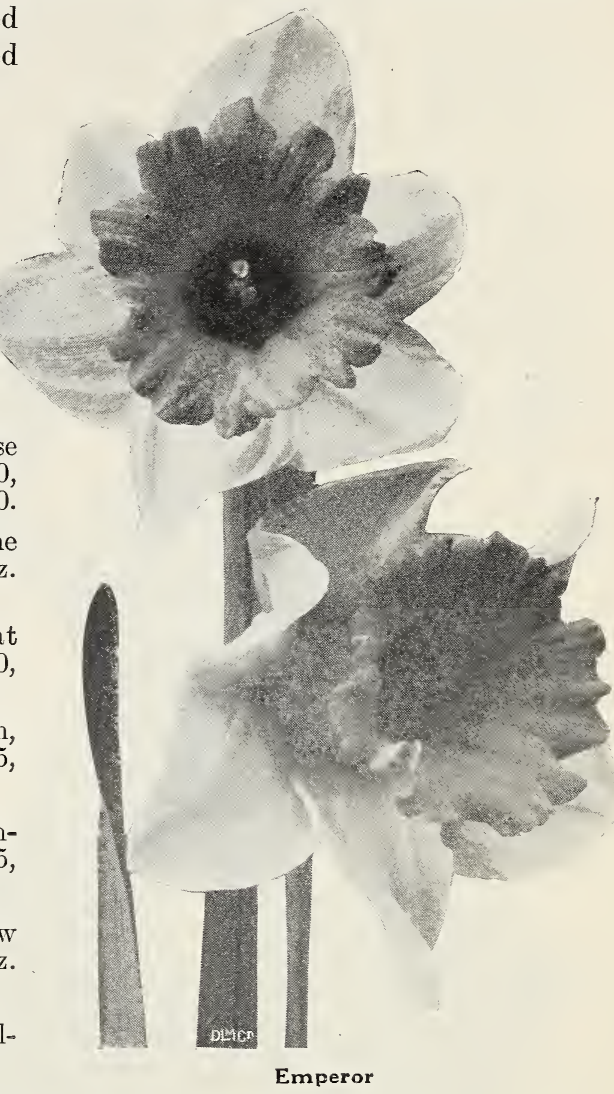


 \\ Medium Trumpet Narcissi}

If by Parcel Post, add postage at zone rates. Weight 1 lb. per doz., 7 lbs. per 100

In this class will be found many of the most graceful and beautiful Daffodils, equally desirable for beds and borders. as well as for indoor cultivation, and especially adapted to nature-garden planting.

Barri Conspicuus. Broad, yellow perianth and wide, short cup, edged with bright orange scarlet. Doz. $\$ 1.50,100 \$ 10.00$.

Incomparabilis Bernardino. Large creamy white perianth, with frilled cup, stained deep orange and apricot. Doz. \$4.00, $100 \$ 30.00$.

Leedsi Evangeline. Large, pure white prianth, soft lemon cup. Doz. \$2.00, $100 \$ 14.00$.

Incomparabilis Lucifer. Handsome white perianth with glowing orange-red cup. Doz. $\$ 2.00$, $100 \$ 14.00$.

Incomparabilis, Sir Watkin (Giant Welsh Chalice Flower). Sulphur-yellow perianth and deep yellow cup; large and handsome. Mother Bulbs. Doz. $\$ 2.00,100 \$ 15.00$.

Leedsi, Mrs. Langtry. Broad, pure white perianth; large, white cup, edged yellow; showy. Doz. $\$ 1.50,100 \$ 10.00$.

Leedsi, White Lady. Broad, round, white overlapping perianth, pale canary cup prettily frilled. Fine Eucharis shaped. Doz. \$2.00, $100 \$ 15.00$.

\section{NARCISSUS JONQUILLA or IONQUILS}

Rugulosus. Rich yellow, sweet scented, fine for cutting. Doz. \$1.50, $100 \$ 10.00$.

\section{Poetaz Hybrids Narcissi}

If by Parcel Post, add postage at zone rates. Weight, 2 lbs. per doz., 12 lbs. per 100

A comparatively new race, resulting from a cross between the Poeticus ornatus and the best sorts of the Polyanthus. They are perfectly hardy, very vigorous, and bear generally three or four flowers on a stem, with the delicate fragrance and size of the Ornatus and the free flowering qualities of the Polyanthus. They are also excellent for growing in pans indoors.

Elvira. Pure white, with yellow eye; a very longstemmed, large flower. Doz. $\$ 2.25$, $100 \$ 16.00$.

Early Perfection. An improved Elvira. Pure white with yellow cup. Can be forced to bloom early in January. Doz. \$2.75, $100 \$ 20.00$.

Horace. Free flowering, splendid forcing variety. Pure white perianth with conspicuous red eye. Doz. $\$ 2.50,100 \$ 18.00$.

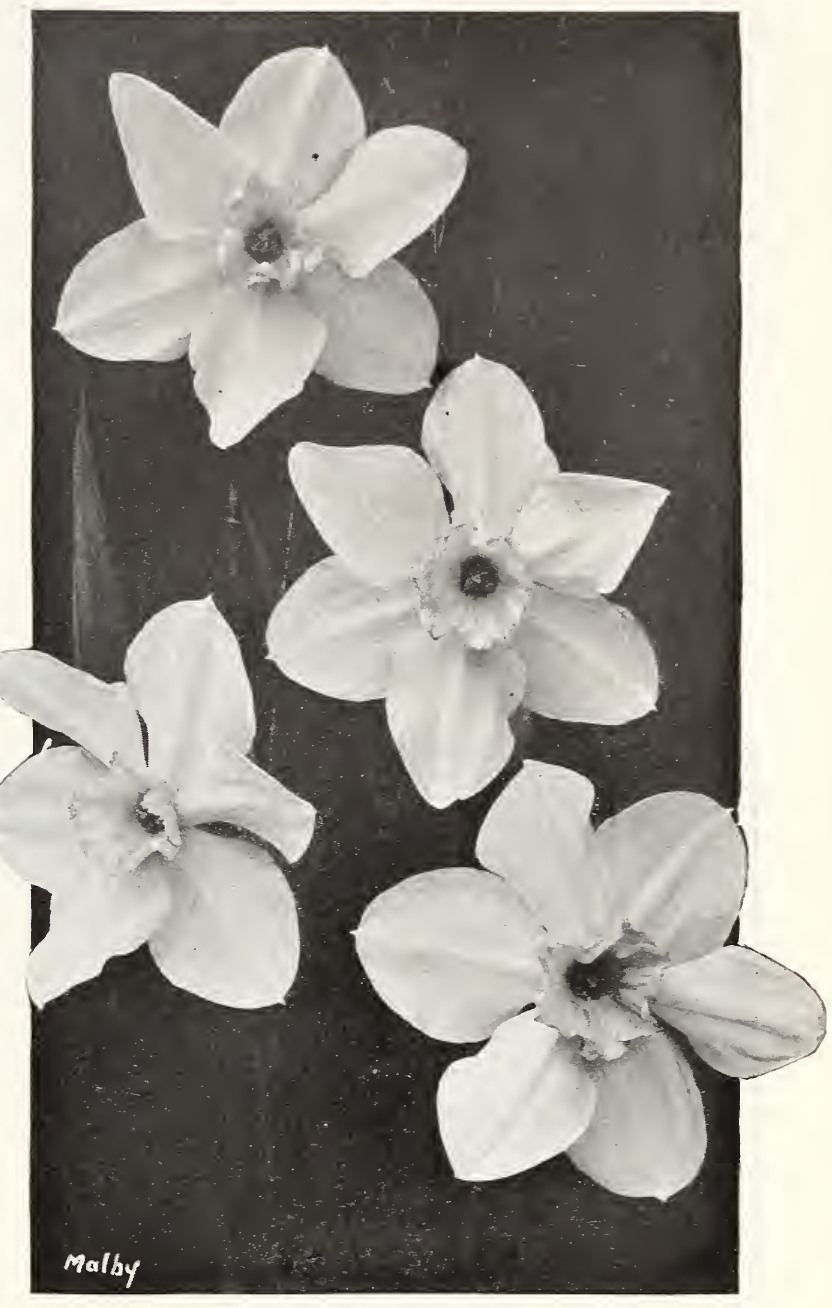

Narcissus Leedsi Evangeline

Laurens Koster. Pure white perianth; large, orangeyellow cup. Doz. $\$ 2.00,100 \$ 15.00$.

Orange Cup. Creamy-white, conspicuous orange cups. A delightful color combination. Doz. $\$ 3.00,1000 \$ 23.00$.

\section{Poeticus Narcissi}

If hy Parcel Post, add postage at zone rates. Weight 1 ib. per doz., 6 lbs. per 100

Poeticus (Poet's or Pheasant-eye). Pure white, with orange crown, edged with scarlet. One of the best sorts for naturalizing. Doz. \$1.25, $100 \$ 9.00$. 


\section{Polyanthus Narcissi}

If by Parcel Post, add postage at zone rates. Weight, 2 lbs. per doz., 12 lbs. per 100

\section{Ready in October}

Excellent for forcing or growing in water, bearing tall trusses of delicately scented flowers. Treat as recommended for Hyacinths. They are not hardy.

Paperwhite srandiflora. The largest, earliest and best of all for forcing. Snowwhite flowers in large trusses. It is superior to the Chinese or any other Narcissus for growing in water with pebbles in shallow dishes. Mammoth Bulbs. Doz. $\$ 1.50,100 \$ 10.00$. Extra Large Bulbs. Doz. $\$ 1.00,100 \$ 7.50$.

Grand Soleil d'Or. This popular variety of the Polyanthus type is easy to grow in pebbles and water. The color is a clear yellow with orange cup. Doz. $\$ 2.25,100 \$ 16.00$.

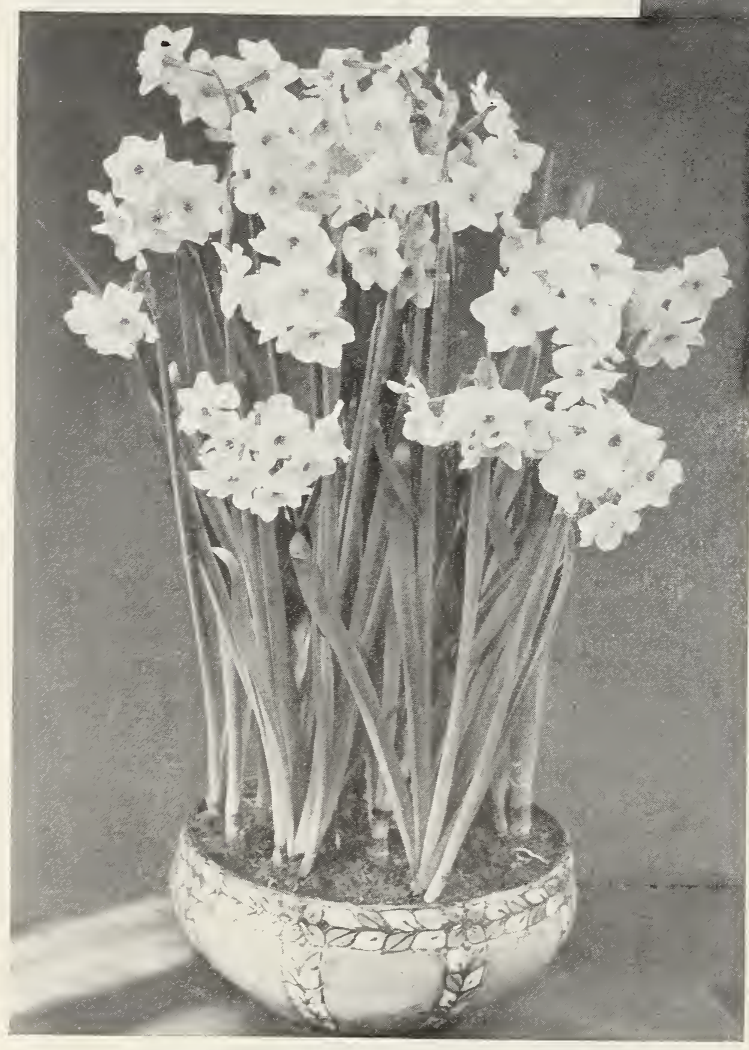

Narcissi Poetaz, Early Perfection. See page 9

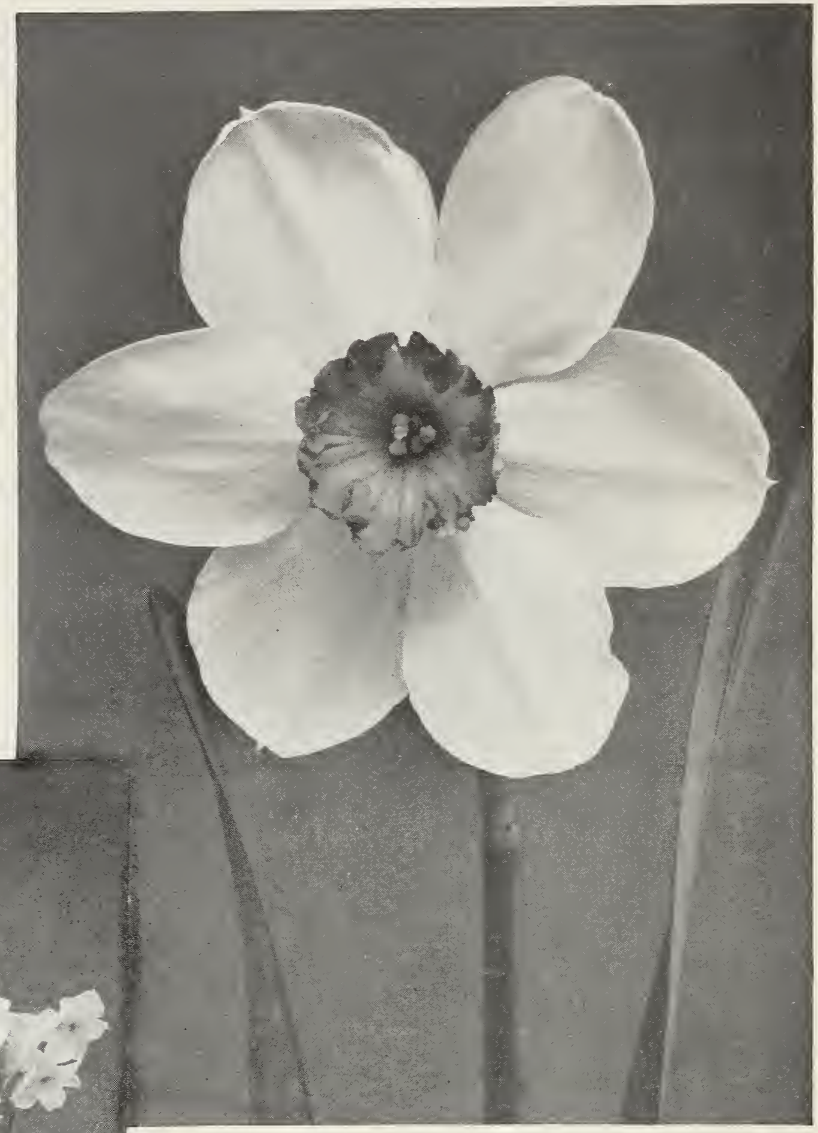

Narcissi Incomparabilis Bernardino. See page 9

\section{Double-Flowering Narcissi}

If by Parcel Post, add postage at zone rates. Weight 2 lbs. per doz., 12 lbs. per 100

The double-flowering Daffodils are perfectly hardy, very popular and well adapted to outdoor planting, no garden being complete without them. They are also excellent for house or conservatory growing in pots or pans.

Primrose Phoenix. Lemon yellow, large roseshaped flower; long stems. Doz. \$2.7., 100 $\$ 20.00$.

Sulphur Phoenix. White with sulphur center, passing off pure white. Doz. $\$ 2.75,100 \$ 20.00$. 


\section{EXHIBITION HYACINTHS}

Culture in Pots or Pans. These may be planted any time from September to November, though early planting as a rule, gives the best results. Firm, heavy bulbs should be selected, and, if to be planted singly, use a 5-inch pot or four bulbs of one variety to an S-inch seed pan. A piece of broken pot placed over the hole and 1 or 2 inches of Sphagnum Moss placed on this, make excellent drainage. A light, rich soil is essential; one made up of one-third rotted cow manure, one-third rotted sod, and the balance of leafmold and sharp sand, is excellent. When planting, break off all offsets, if any, at the base of the bulb and have the top of the bulb just below the soil, and the soil about an inch below the top of the pot; give a good watering; put in a cool place and cover with 5 or 6 inches of sand or sifted coal ashes; this prevents the bulbs from rising while they are making roots and holds the moisture. After eight weeks the roots should be strong enough to allow them to be brought to the light and into the room where they are to bloom.

Culture in the Open Garden. Bulbs may be planted from September until the ground closes, although the best results will be obtained if planted before the end of October. Plant 6 inches deep and 6 inches apart, in soil which has been dug at least 12 inches deep and well enriched with well-rotted cow manure. Before the ground freezes deep enough to reach the bulbs, cover with leaves or other good litter, 6 to 8 inches deep, to protect the bulbs from freezing and thawing through the Winter, thus being assured of larger and stronger spikes of bloom. The covering should be removed early in the Spring.

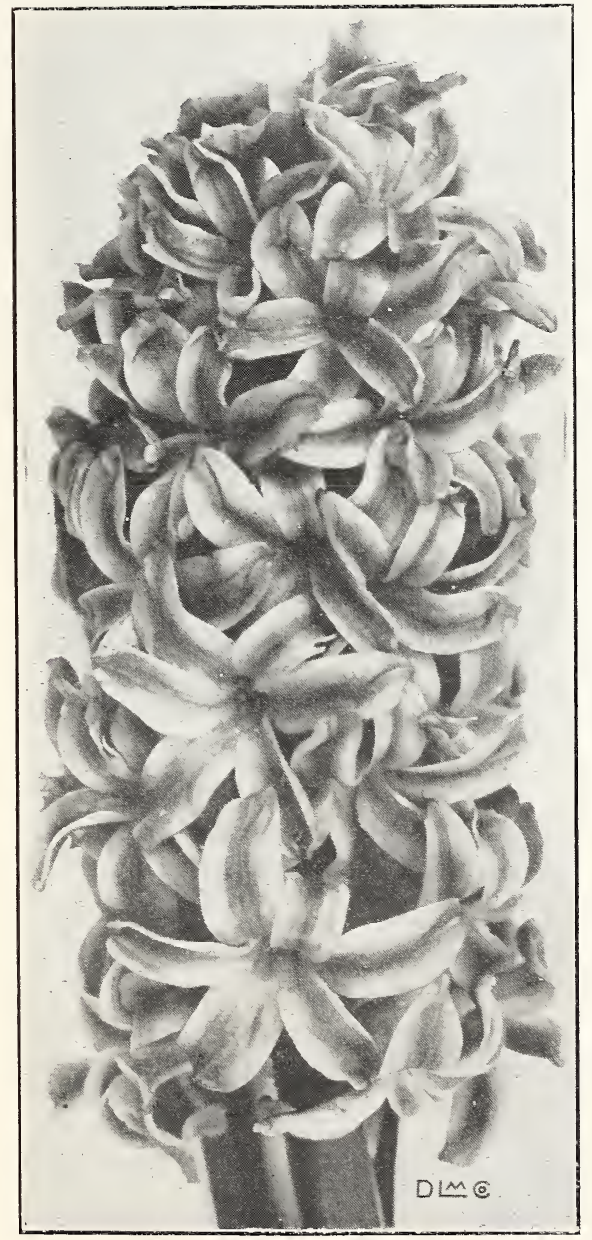

King of the Blues
These are all extra selected bulbs of large size and the best varieties for exhibition purposes and house culture.

If by Parcel Post, add postage at zone rates. Weight, 3 lbs. per doz.

Each 35c., doz. $\$ 3.75,100 \$ 28.00$

\section{Single Pink, Rose and Red}

Cardinal Wiseman Dark pink; large, full spike, fine for
late forcing.

Garibaldi. Bright crimson; large truss, early, excellent for forcing.

General de Wet. Pleasing soft pink with white throat; large spike.

Gertrude. Dark pink; large spike; a most popular pot and bedding sort.

Lady Derby. Beautiful, bright rose-pink; a lovely shade; Marconi. Bright rose; fine forcer.

Moreno. Lively pink; large bells and spike; an early and popular sort.

Pink Perfection. Fine delicate pink, shaded lavender; very distinct.

Oueen of Pinks. Brilliant, clear, bright pink; large, full spike: very compact.

\section{Single Pure White}

Arentine Arendsen. Snow-white, perfect spike, with wide open petals; extra.

British Queen. Pure white; large, perfect truss of good sized bells.

La Grandesse. Snow-white; large, compact spikes; fine bells,

L'Innocence. Pure white; large spike; excellent for all purextra for exhibition. poses. 


(19) THOMAS J. GREY COMPANY T. Th

\section{EXHIBITION HYACINTHS-Continued}

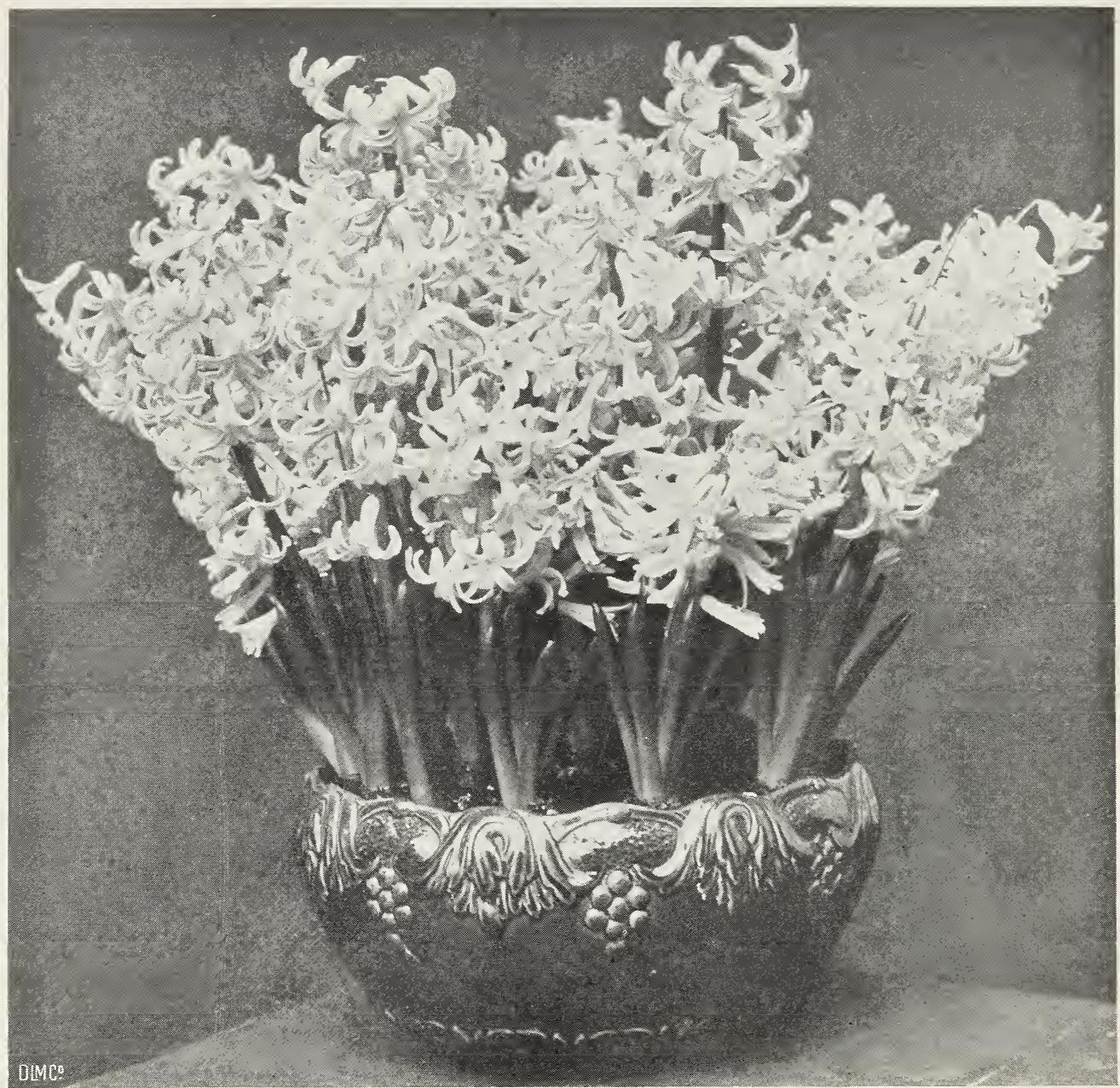

ROMAN HYACINTHS (See Page 13)

Single Blue, Purple and Violet

Each 35c., doz. $\$ 3.75,100 \$ 28.00$

Admiral Courbet. Deep azure blue, enormous truss, early.

Bismarck. Sky-blue, very broad spike and excellent for early forcer.

Czar Peter. Light lavender-blue; splendid spike; an old favorite.

Enchantress. Delicate, light blue; beautiful truss on Felix Faure. Porcelain-blue; large bells.

Grand Maitre. Deep lavender-blue; elegant loose spike of immense size.
King of the Blues. Rich, dark blue; large spike, Nador. Deep blue; large flower and a splendid forcer, as well as a bedder.

Queen of the Blues. Azure-blue; large spike, forces

\section{Single Yellow and Orange \\ Each 35c., doz $\$ 3.75,100 \$ 28.00$}

City of Haarlem. Golden yellow; large and well Yermed truss.

Yellow Hammer. Pure yellow with beautiful truss; early. 


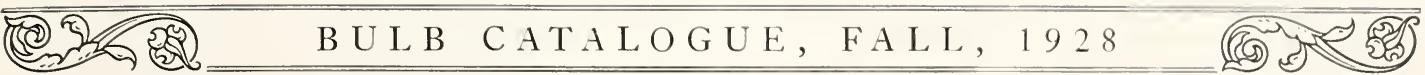

\section{Early Roman Hyacinths}

These are specially adapted for house culture and forcing, each bulb giving from three to six spikes. By early and successive plantings they may be had in bloom throughout the Winter. If well rooted and brought into heat by the middle of November they may be had in bloom for Christmas.

If by Parcel Post, add postage at zone rates. Weight per doz. 2 lbs.

Pure White. Mammoth bulbs........ P Prices

Light Blue. Selected bulbs............ on

Light Pink. Selected bulbs.......... application

French Grown l'Innocence. Excellent for forcing

Dutch grown. Produces extralargespikes. Qun than limited.

\section{Miniature Hyacinths}

These are also known as Dutch Romans and Pan Hyacinths. They are small, single flowering Dutch Hyacinths, and are very suitable for growing in pans, pots or boxes, using one variety only to each pan, to insure their all blooming at the same time. They are also fine for outdoor planting.

If by Parcel Post, add postage at zone rates. Weight per doz. 2 lbs.

Gigantea. Blush pink. Queen of Blues. Azure King of Blues. Dark blue

La Grandesse. Snow white.

L'Innocence. Pure blue.

white.

Yellow Hammer. Pure yellow with beautiful truss.

$\$ 1.50$ per doz., $\$ 10.00$ per 100 .

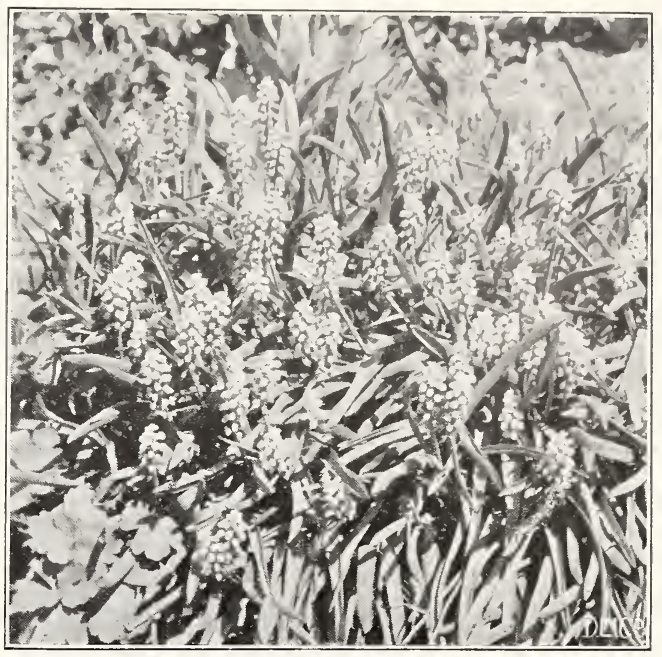

Grape Hyacinths

\section{Grape Hyacinths}

One of the prettiest early Spring flowering bulbs, Perfectly hardy. Excellent for naturalizing and for edgings or clumps in the shrubbery border. Very effective and succeed in almost any situation. For house growing they are very pretty and interesting.

\section{No charge for mailing.}

Coeruleum. Bright blue. Doz. 40c., $100 \$ 2.50$. Heavenly Blue. Large, sky-blue. Doz. 45 c., $100 \$ 3.50$.

\section{Special Named Bedding and Forcing Hyacinth Plants}

These are large, solid bulbs of distinct and decided shades, producing large spikes of flowers, and all blooming at the same time, which makes them of great value for bedding out, as one can obtain the exact color effect desired. They are also desirable for forcing in pots or pans.
Special Bright Red
Special Crimson
Special Pink
Special Pure White
Special Dark Blue
Special Blush White
Special Light Blue
Special Rose
Special Porcelain Blue

Doz. $\$ 2.75,100 \$ 20.00$.

If by Parcel Post, add postage at zone rates. Weight, 2 lbs. per doz.

\section{Selected Unnamed Hyacinths}

These are sound, healthy flowering bulbs, superior to the mixed Hyacinths usually offered, and are well adapted to outdoor planting or forcing, giving good spikes of flowers in fine colors.

Select Dark Red

Select Rose
Select Pure White

Select Dark Blue
Select Light Blue

Select Yellow

Select Mixture of Above Sorts

Single Flowering Bulbs, Doz. \$2.00, $100 \$ 15.00$.

If by Parccl Post, add postage at zone rates. Weight, 2 lbs. per doz. 


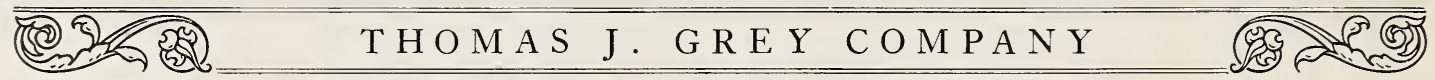

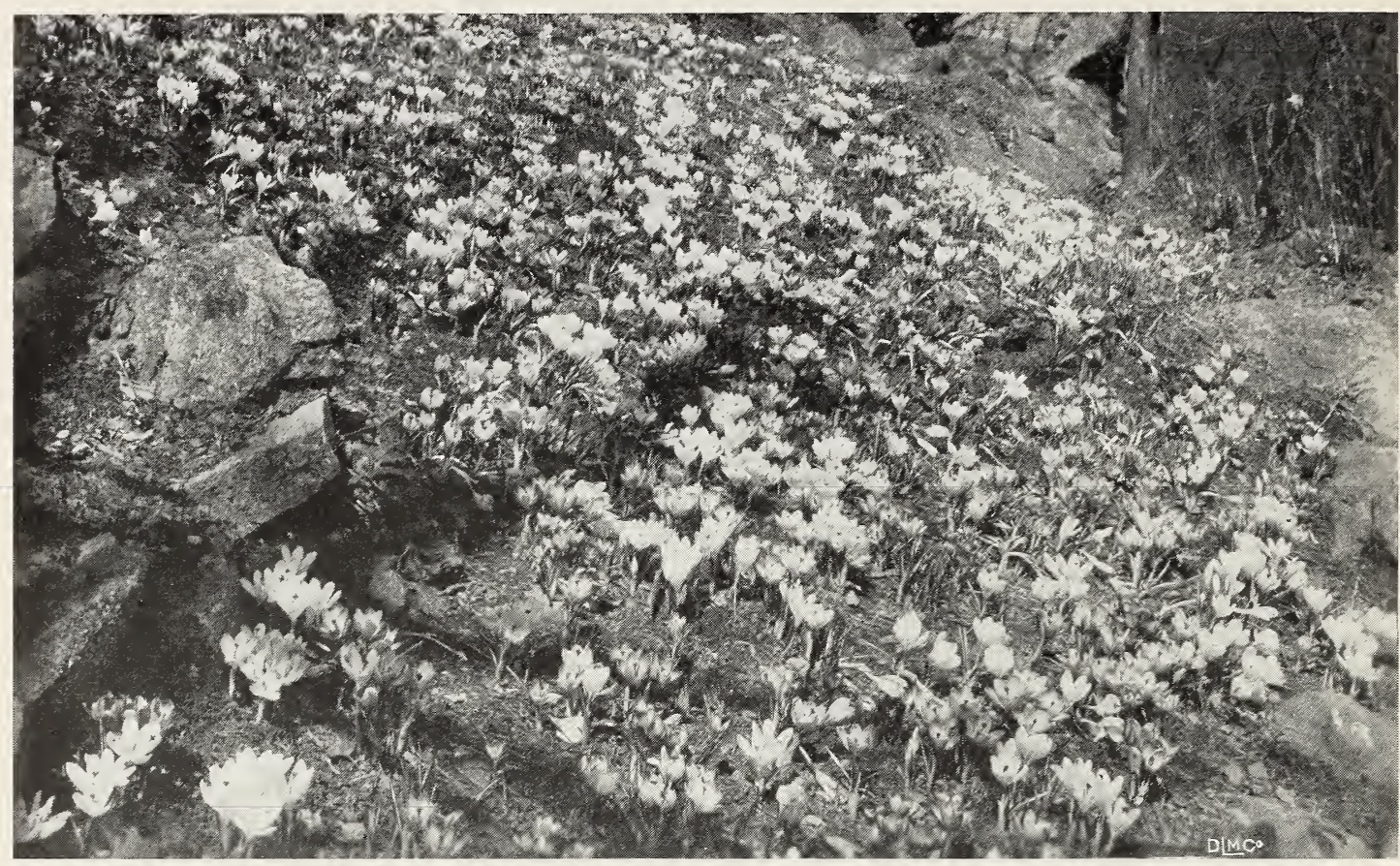

\section{CROCUS, Giant Flowering}

One of our earliest Spring flowers. Beautiful and a universal favorite. A bed, border or some clumps of these are essential to make the flower garden complete. To be had in the highest perfection, they should be planted 3 inches deep, in a deep, rich, sandy loam, and in a sunny location, though they will succeed in almost any soil or situation. When planted in connection with Chionodoxa, Snowdrops or Scilla they are very effective. They also may be grown indoors in bulb pans, etc., as recommended for Hyacinths. Best results outside are obtained from early planting.

If by Parcel Post, add postage at zone rates. Weight, 3 lbs. per 100. Postage paid at doz. price.

\section{BLUE AND PURPLE SORTS}

Baron von Brunow. Large; dark blue; free flowering; extra. Doz. 55c., $100 \$ 3.50,1000 \$ 30.00$.

Caesar. Beautiful, deep purple; very large. Doz. $75 \mathrm{c}$, $100 \$ 5.00,1000 \$ 45.00$.

King of the Blues. Dark purple; extra fine. Doz. 75 c., $100 \$ 5.00,1000 \$ 45.00$.

Lord Palmerston. Bright purple; one of the best. Doz. 55c., $100 \$ 3.50,1000 \$ 30.00$.

\section{WHITE SORTS}

Kathleen Parlow. Extra choice, pure white variety, large orange anthers. Doz. 75c., $100 \$ 5.00,1000$ $\$ 45.00$.

King of the Whites. The best and largest white. Doz. $75 \mathrm{c} ., 100 \$ 5.00,1000 \$ 45.00$.

Mont Blanc. Large, snow white; extra. Doz. 60c., $100 \$ 4.00, .1000 \$ 35.00$.

Page fourteen

\section{STRIPED SORTS}

Albion. Purple, white feathered. Doz. 60c., 100 $\$ 4.00,1000 \$ 35.00$.

Madam Mina. Large; light blue, striped; early. Doz. 60c., $100 \$ 4.00,1000 \$ 35.00$.

Pallas. White ground, light lilac stripes; showy orange anthers. Extra large. Doz. 75c., $100 \$ 5.00$, $1000 \$ 45.00$.

Sir Walter Scott. White, striped with purple. Doz. 55c., $100 \$ 3.50,1000 \$ 3000$.

\section{YELLOW CROCUS}

Mammoth Golden Yellow. Large bulbs, giving many blossoms. Doz. 85c., $100 \$ 5.75,1000 \$ 55.00$.

Golden Yellow. Extra large. Doz. 60c., $100 \$ 1.00$, $1000 \$ 35.00$.

Giant Mixture. From named sorts. Doz. 65c., $100 \$ 4.25,1000 \$ 40.00$ 


\section{ANEMONES}

These popular flowers of French origin are useful as a decorative plant for house or garden and fine for cutting. Plant in October or November.

Single De Caen Mixed. Doz. 85̃c., $100 \$ 6.00$.

\section{CALLA LILIES}

(Richardia)

If by Parcel Post, add postage at zone rates. Weight, 3 lbs. per doz.

An old and well-known favorite for house culture, requiring a rich soil, plenty of light, heat and water while growing. Allowing them to rest from June to last of August, and then repotting will greatly aid in the profusion of bloom. When showing flower spike an additional top-dressing of sheep manure will add to size of flower and foliage.

White Calla, or Lily of the Nile. (R. Aethiopica)

Largest Sized Bulbs. Each 35c., doz. $\$ 4.00$.

Elliottiana (Golden Calla). Rich, clear, golden yellow, the dark green foliage spotted with white. Each 50c., doz. $\$ 5.00$.

\section{CHIONODOXA (Glory of the}

No charge for mailing.

One of the most beautiful and effective of our Springflowering bulbs, coming into bloom soon after the snow is gone, and lasting a long time. They succeed well in any good garden soil, and are excellent for clumps; edgings or naturalizing.

Luciliae. Brilliant sky-blue, with white center. $45 \mathrm{c}$. per doz., $\$ 3.00$ per 100 .

Sardensis. Intense bright blue. 60c. per doz., $\$ 4.00$ per 100.

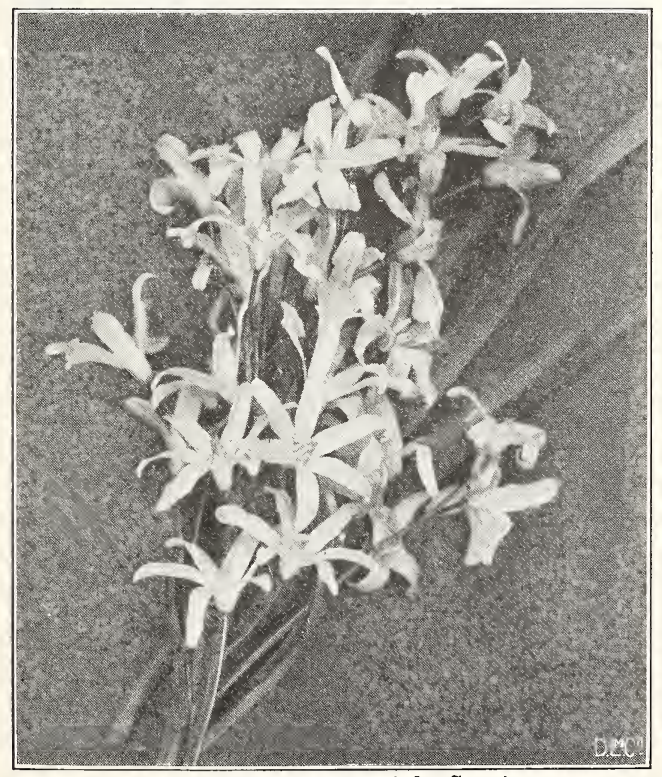

Chionodoxa (Glory of the Snow)

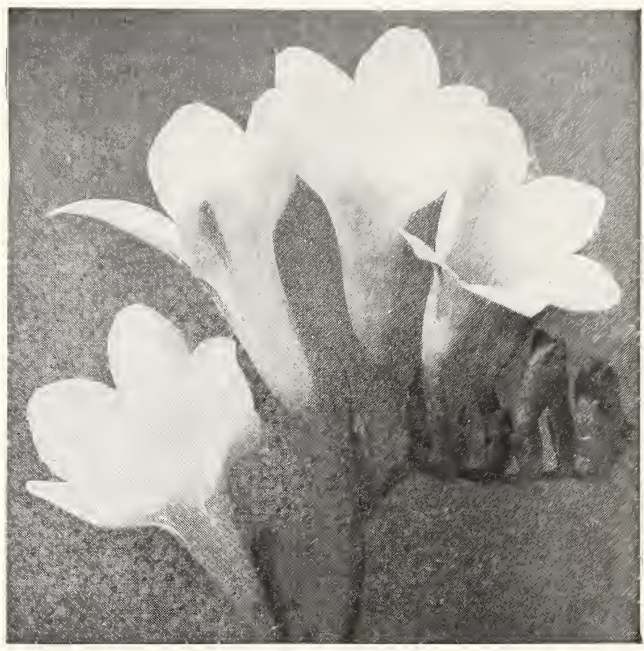

Freesia Purity

\section{FREESIAS}

Mailed at doz. and 100 prices.

Probably no flower is better known, or more popular than the Freesia, with its beautiful, graceful and delicately perfumed flowers. They are especially suited to house and greenhouse growing, and excel as a cut flower in the length of time they may be kept fresh; easily forced and may be had in bloom from January to June. Plant eight to twelve bulbs in a 6-inch bulb pan and cover 1 inch.

Fischer's Purity. The finest and purest white sort yet introduced. Our stock is grown from the $\begin{array}{llll}\text { originator's. } & \text { Doz. } 100 & 1000\end{array}$

Mammoth Bulbs...........\$0.75 $\$ 5.00 \$ 45.00$ Extra Large Bulbs . . . . . . . . . . . $\quad .60 \quad 4.00 \quad 35.00$ Large Bulbs............ .40 $3.00 \quad 25.00$

\section{NEW COLORED FREESIAS}

\section{Extra Large Bulbs}

Amethyst. Lavender mauve. Doz. $\$ 1.10,100 \$ 8.00$. CARRIE BUDAU. Lavender-pink; a great improvement over Gen. Pershing; larger flowers and heavier stems. Doz. $\$ 1.10,100 \$ \$ .00$.

Mendota. The best yellow yet introduced. Doz. $\$ 1.50,100 \$ 10.00$.

Mrs. Marc Peter. Deep rosy-salmon with lower petals blotched orange and yellow. Doz. $\$ 1.50,100$ $\$ 9.50$.

OLIVETTE. Bright carmine-red with light yellow throat; lower petals deep yellow blotch with crimson veins. Doz. $\$ 1.10,100 \$ 8.50$.

Yellow Prince. Slightly darker than California and much stiffer stems. Doz $\$ 1.25,100 \$ 8.50$.

GOLDEN DAFFODIL. This new variety is a rich Daffodil yellow. Flowers are large, and are borne on long, stiff stems. Doz. $\$ 1.50$, $100 \$ 12.00$.

SPLENDENS. A beautiful deep lavender, borne on long, stiff stems. Doz. $\$ 1.00,100 \$ 7.00$. 


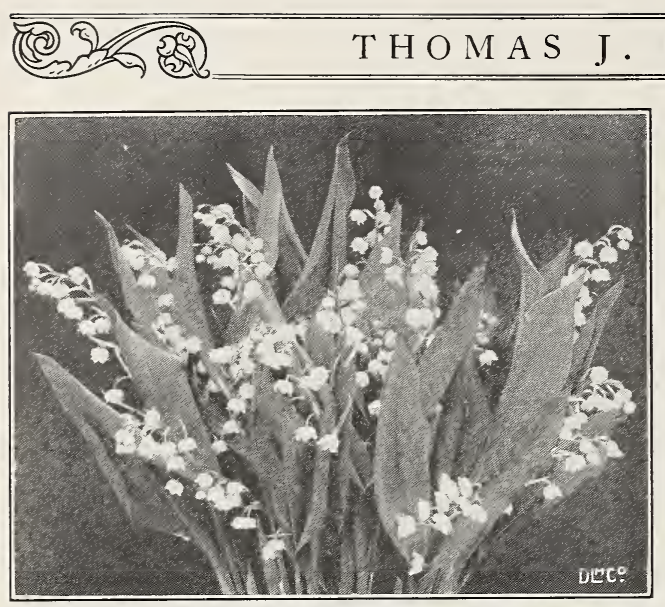

Lily of the Valley

\section{IRIS IMPERATOR}

To obtain the best results, grow in pans in a compost of loam, rotted cow manure and leafmold with a little bonemeal added. After potting, plunge in sifted coal ashes to the brim and cover with 4 inches of sand and water thoroughly. When they show above the sand bring inside and then flower in temperature of 45 to 50 . Don't try to force at first. The color is brilliant blue and is the best forcer.

Mammoth Bulbs. Doz. $\$ 1.75,100 \$ 12.00$.

\section{IXIAS}

Charming bulbs for Winter blooming. They are very easily grown. The colors including shades of yellow, white, pink and red. Plant six to eight bulbs in a 6 -inch pan. Ten fine varieties in separate colors. Doz. $75 \mathrm{c} ., 100 \$ 5.00$.

Mixture.' Doz. 50c., $100 \$ 3.00$.

\section{LILY OF THE VALLEY \\ (Convallaria)}

Grey's Perfect Forcing Pips. The finest grade of pips that come to this country and especially selected for our large private trade, which demands only the best, for forcing throughout the year. We carry these in cold storage and can furnish them at any time. Three to four weeks are usually allowed for forcing cold storage pips into flower. Per case of $250 \$ 16.00$; per case of $500, \$ 30.00$.

\section{SCILLAS}

No charge for mailing.

Sibirica. Showy spikes of bright blue flowers. Largely used in lawns in combination with Snowdrops and Crocus. Also very effective for naturalizing. Height 4-5 inches. Doz. 75c., $100 \$ 5.00$.

Campanulata. These bulbs are used extensively for naturalizing, flowering well in shady places. Beautiful spikes of Hyacinth-like flowers. Planted in clumps give best results.

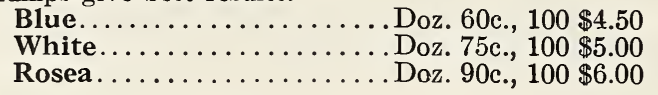

\section{OXALIS}

No charge for mailing.

Particularly adapted for pots and hanging baskets in the house or conservatory. Plant four to six bulbs an inch deep in a 5-inch pot, using sandy loam. Grow and bloom best in a moderate temperature. These bulbs reach us about August 1st and if planted about that time should be in flower about Christmas and continue throughout the winter.

Buttercup. Pure bright yellow.

Mammoth Bulbs. Doz. 50c., $100 \$ 3.50$.

Grand Duchess. Of dwarf, sturdy habit, with large flowers in the greatest profusion on strong stems. well above the foliage, from November until June. Excellent pot plant. In three colors.

Lavender, Pink and Pure White. Doz. 40c., $100 \$ 2.75$.

\section{SNOWDROPS (Galanthus)}

\section{No charge for mailing.}

There is no more general favorite among the earliest Spring flowers than the Snowdrop. It is among the bardiest and they flourish in any soil or situation. They should be planted 3 inches deep.

Single Flowering.............Doz. 60c., $100 \$ 4.00$

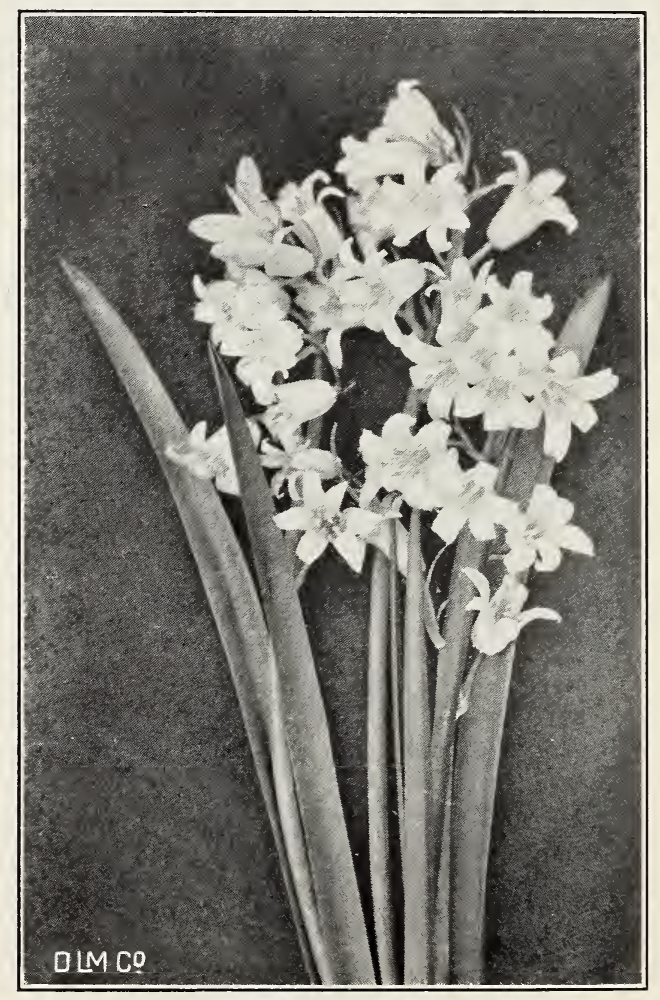

Scilla campanulata 


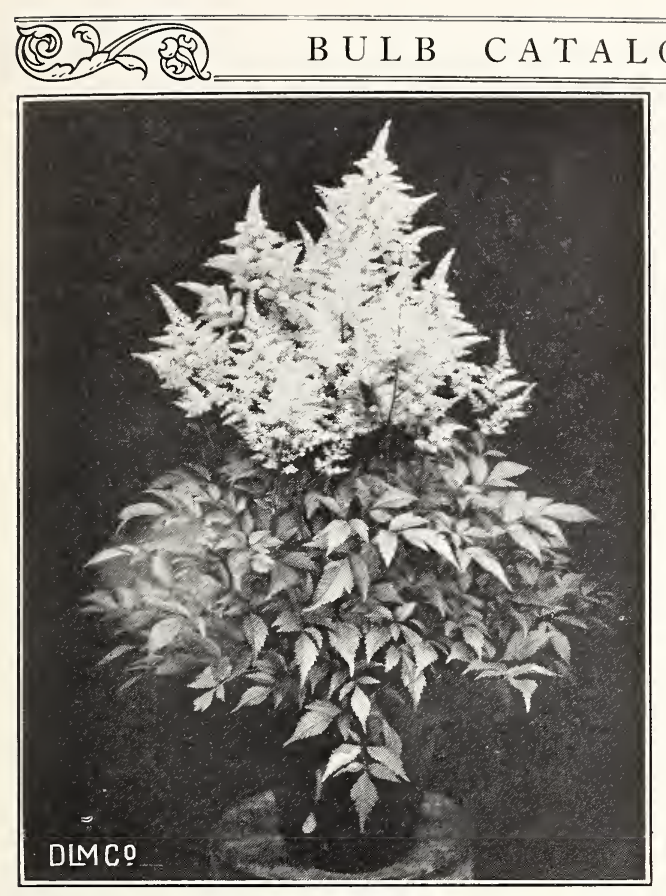

Spiraea Gladstone

\section{PAEONIES}

Couronne d'Or. Pure white globular flowers, with amber-yellow stamens, center petals tipped carmine. Each $\$ 1.50$.

Delachei. Dark red Peonies. Vigorous growth, flowering somewhat later than most varieties. Each $\$ 1.00$.

Dorchester. Large and compact. Pale hydrangeapink. Fragrant. Each \$1.50.

Duchess de Nemours (Calot). Medium-sized pure white bloom. Strong, free bloomer. Each 75c.

Duke of Wellington. Large, bomb type. Guards white, center creamy-yellow. Each $75 \mathrm{c}$.

Edulis Superba. A beautiful early variety. Double rose pink. Each $\$ 1.00$.

Felix Crousse. Large, globular bloom. Brilliant red and a free bloomer. Each $\$ 1.50$.

Festiva Maxima. Very large; pure white center, petals tipped with bright crimson. Each 75c.

Germaine Bigot. Color pale rose, blooming with the midseason varieties. Each $\$ 1.50$.

Golden Harvest. Rose guard petals, yellow petaloids, tufted pink center. Each $75 \mathrm{c}$.

La Tulipe. Large pink buds, striped with crimson, opening pale pink. Each $75 \mathrm{c}$.

Venus. A delicate shell-pink. Compact bloom. Each $\$ 1.50$.

Jeanne d'Arc. Peach-pink, shading to a creamy white. Each $\$ 1.00$.

Louis Van Houtte. Medium-sized bloom. Deep carmine-rose with fiery reflex; fragrant. Each $75 \mathrm{c}$.

Madame de Verneville. Very large; pure white with center petals blush, tipped carmine. Each $75 \mathrm{c}$.

\section{RANUNCULUS}

The bulbs resemble tiny clumps of Dahlia roots. They are grown much the same as Anemones. Should be grown in a cool greenhouse. Plant about 8 roots in a 6 -inch bulb pan.

Giant Double French Mixed. Doz. 90c., $100 \$ 6.50$.

\section{SPIRAEA}

These beautiful pot plants commonly forced by florists for Easter. Also very satisfactory for outside planting.

\section{Ready December 1st}

Gladstone. Best white for forcing.

Queen Alexandra. Beautiful pink variety of proven merit.

Peach Blossom. Pale rose forcing variety for Easter.

Strong clumps of any of the above varieties, each $75 \mathrm{c}$., doz. $\$ 7.50$.

\section{TRITONIA CROCATA}

Attractive bulbous plants for pot culture ranging from bright orange to deep orange scarlet. Plant 6 to 8 in a 6-inch pot.

$$
\text { Doz. 85c., } 100 \$ 6.00 .
$$

One of the hardiest flowering plants and rivaled only by the Rose.

Monsieur Jules Elie. Large, compact. Pale lilacrose with silvery reflex; fragrant. Each $\$ 2.00$.

Rosea su perba. Large blooms of brilliant cerise-pink. Strong and vigorous. Each $\$ 1.25$.

Walter Faxon. Large blooms; bright rose deepening toward the center; fragrant. Each $\$ 5.00$.

Officinalis, alba, rubra, rosea. Each $\$ 1.50$.

Mixed. Each 60c., doz. $\$ 6.00$.

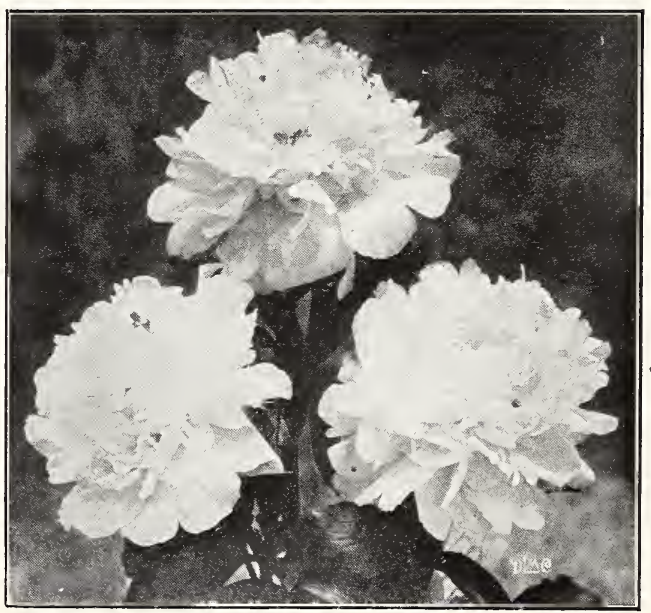

Paeonia Festiva Maxima

Page seventeen 


\section{LILIES FOR FORCING}

If by Parcel Post, add postage at zone rates. Weight, 3 lbs. per doz.

Bulbs should be potted in a rich soil, using 31/2- to 6 -inch pots, according to the size of the bulb, and the pots plunged in a coldframe, or kept in a cool place, to get a strong root-growth. When well rooted and started 6 or 8 inches they should be shifted into larger pots to bloom, setting the bulb considerably deeper. A suitable compost is equal parts of turfy loam, leafmold, rotted cow manure and sand. Bulbs should be potted as soon as received.

\section{Candidum Madonna Lily}

(Arrive in September)

Mammoth Northern-Grown. These are of the large-flowered, pure white, thick-petaled variety and grown for us in the north of France. Excellent for forcing and superior as a garden Lily. Southerngrown bulbs should be avoided, as they are thinpetaled and badly diseased. Each 50c., doz. $\$ 5.00$, $100 \$ 40.00$.

Extra Large. Doz. $\$ 4.00,100 \$ 30.00$.

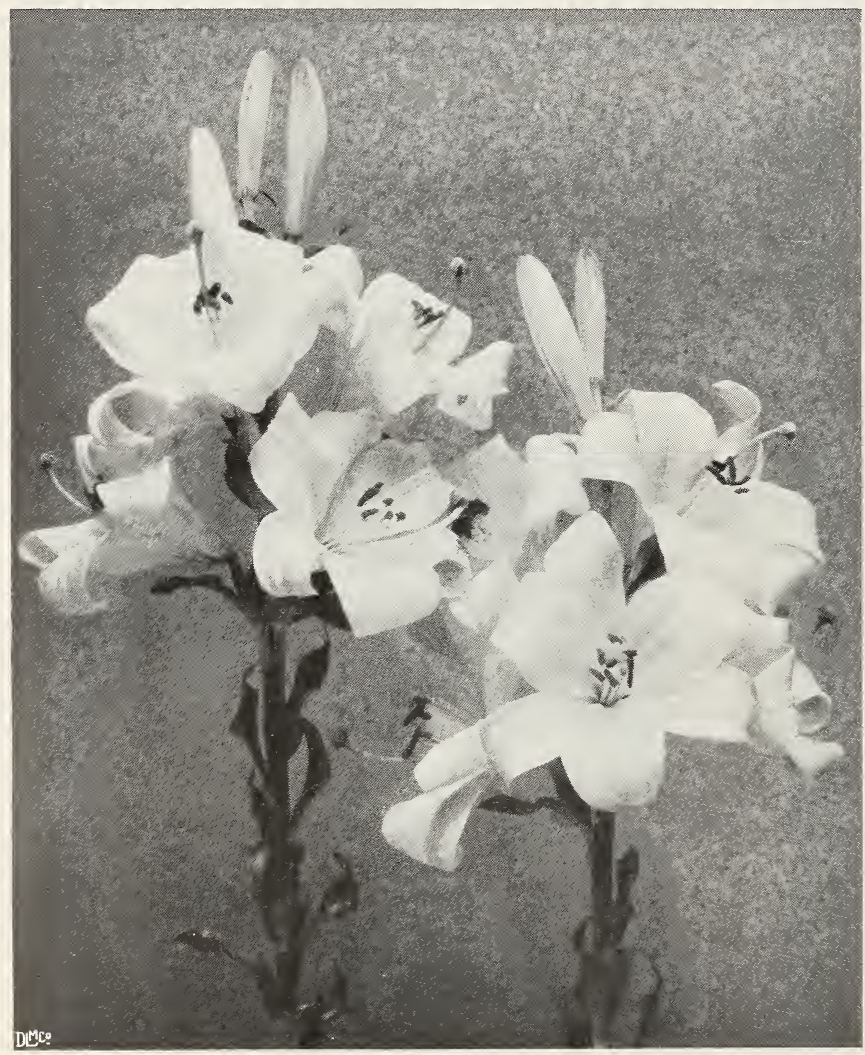

Lilium Candidum

\section{Longiflorum formosum}

(Arrive in September)

The type of the $L$. longiflorum which comes from the island of Formosa is becoming more popular every season. It is of strong, healthy growth, 2 to 3 feet high, with beautiful, white, trumpet-shaped Lilies about 6 inches long, and may be had in bloom from early December to Easter.

Extra Large Bulbs. 7 to 9 in. Each 40 c., doz. $\$ 4.00$, $100 \$ 35.00$.

Mammoth Bulbs. 9 to 10 in. Each 70c., doz. $\$ 7.50,100 \$ 60.00$.

Special Mammoth Bulbs. 11 to 13 in. Each 95c., Doz. $\$ 10.00,100 \$ 80.00$.

\section{Harrisi}

\section{Bermuda Easter Lily \\ (Arrive in July)}

Choice, thoroughly ripened stock from the best growers in Bermuda.

Extra Large Bulbs. 7 to 9 in. circumference. Each 60c., doz. \$5.75, 100 $\$ 45.00$.

Mammoth Bulbs. 9 to 11 in. circumference. Each $\$ 1.00$, doz. $\$ 10.00,100$ $\$ 80.00$.

\section{Longiflorum giganteum (Arrive in October)}

The latest type of all the Longiflorum Lilies and the one most extensively used for Easter flowering. They are of stocky growth with dark stems and are unusually free from disease. The flowers are of the largest size and purest white. This variety is carried in cold storage for blooming at any desired time throughout the season.

Extra Large Bulbs. 7 to 9 in. Each 40c., doz. $\$ 3.75,100 \$ 30.00$.

Mammoth Bulbs. 9 to 10 in. Each $55 \mathrm{c}$. , doz. $\$ 5.50,100 \$ 45.00$. 


\section{HARDY LILIES FOR THE GARDEN}

With few exceptions they prefer a light, well-drained, loamy soil and partial shade. Deep planting is recommended, from 6 to 12 or more inches, according to variety, and a covering of leaves or some litter to prevent the frost reaching the bulbs, as it is absolutely necessary for their success that the bulb be protected from freezing and thawing. Some varieties are ready in August, and others not before November and December, and to insure the planting of the late arrivals the place should be covered to keep the frost nut.

Auratum (Golden-rayed Lily of Japan). Large; pure white, with crimson spots and a gold band through center of each petal. 3 to $5 \mathrm{ft}$. July to Oct.

Extra Large Bulbs. Each 40c., doz. $\$ 4.00,100$ $\$ 30.00$.

Mammoth Bulbs. Each 50c., doz. $\$ 5.00,100 \$ 40.00$. Special Mammoth, 11-13. Each 70c., doz. $\$ 7.50$, $100 \$ 55.00$.

Canadense flavum. Bright yellow spotted with black. 2 to $3 \mathrm{ft}$. June and July. Each 25c., doz. $\$ 2.50,100 \$ 20.00$.

Croceum. Orange, spotted black. Fine form and coloring. June. Doz. $\$ 5.00$.

Hansoni. Deep golden yellow-colored flowers. Jıly. Each $\$ 1.50$, doz. $\$ 10.00$.

Henryi (Yellow Speciosum). Beautiful Lily from China. Rich, apricot yellow, reddish-brown spots. 5 ft. July and Aug. Each 75c., doz. \$7.50, $100 \$ 60.00$.

Krameri. Beautiful, delicate pink. Fragrant, trumpet-shaped flowers, $3 \mathrm{ft}$. July and Aug. Each 40c., doz. $\$ 4.00,100 \$ 30.00$.

Martagon. Purplish crimson, with dark spots. $3 \mathrm{ft}$. July and August. Doz. $\$ 3.50$.

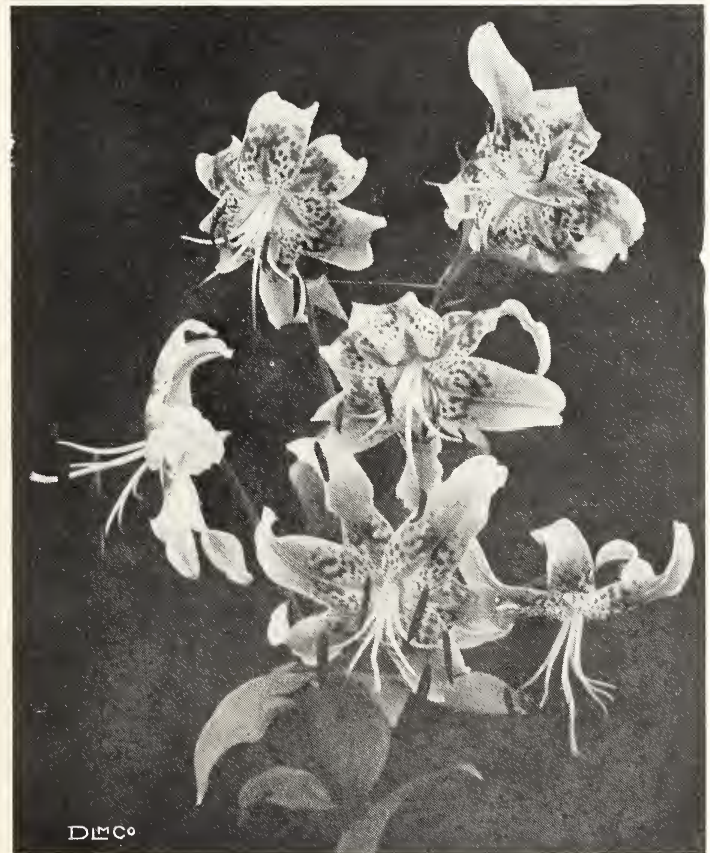

Lilium speciosum $\mathrm{r}$ sbrum

PRICES SUBJECT TO CHANGE WITHOUT NOTICE

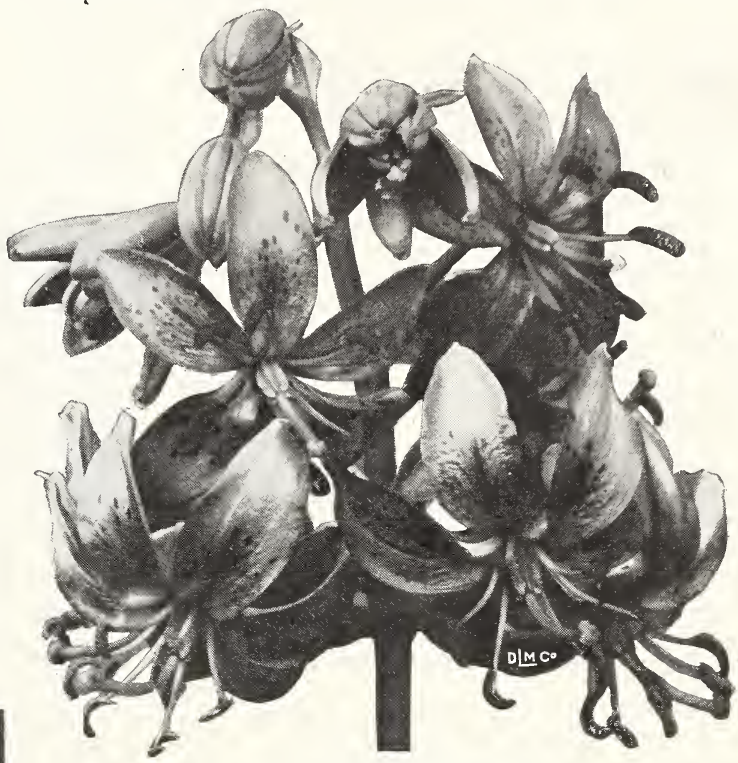

Lilium Hansoni

Speciosum album (Japan Lily). Large; fragrant; pure white.

Large Bulbs. Each 50c., doz. $\$ 4.50,100 \$ 35.00$.

Speciosum magnificum. Large white, heavily spotted with rich red.

Mammoth Bulbs. Each 60c., doz. $\$ 6.00,100 \$ 45.00$.

Special Mammoth, 11-13. Each 70c., doz. \$7.50, $100 \$ 55.00$.

Speciosum Melpomene. White, suffused and spotted with darkest crimson.

Large Bulbs. Each $40 \mathrm{c}$. , doz. $\$ 3.75,100 \$ 30.00$.

Mammoth Bulbs. Each 60c., doz. $\$ 6.00,100 \$ 45.00$.

Speciosum rubrum, or roseum. White, shaded and spotted rosy crimson.

Large Bulbs. Each 40c., doz. $\$ 3.75,100 \$ 30.00$.

Mammoth Bulbs. Each 60c., doz. $\$ 6.00,100$ $\$ 45.00$.

Special Mammoth, 11-13. Each 70c., doz. \$7.50, $100 \$ 55.00$.

Superbum (Native Turk's Cap). Rich orange, petals tipped with red, and spotted. 4 to $6 \mathrm{ft}$. July. Each 25c., doz. $\$ 2.50,100 \$ 20.00$.

Tigrinum splendens (Improved Tiger Lily). Orangesalmon, spotted with black; immense bulbs. $4 \mathrm{ft}$. Aug. Each 15c., doz. $\$ 1.50,100 \$ 10.00$.

$P a g=$ nineteen 


\section{Pot-grown Strawberry Plants}

The Strawberry will grow in any good garden soil where the ground has been thoroughly prepared. For family use we recommend planting them in double rows, 1 foot apart each way and 3 feet between the double rows. Our pot-grown Strawberry plants are well-rooted, healthy plants, ready for shipment in August, and by setting them any time during August and September, a fine crop of fruit may be had the next season. The following sorts have proved the most satisfactory for growing in this locality.

$\$ 7.00$ per $100, \$ 60.00$ per $1000: 50$ at 100 rate, 500 at 1000 rate.

Abington. Strong grower and great yielder. The bright red berries are of very large size, firm and fine flavor. Early to medium.

Arabine. Extra early, very large, bright red of high quality, very robust grower and heavy cropper.

Barrymore. Awarded silver medal and three first premiums by the Massachusetts Horticultural Society, in 1908. A great berry for all purposes. Large size, rich, dark, glossy crimson color; conical shape; flesh red and quality excellent. Medium.

Big Joe. A magnificent new Strawberry of robust growth and very prolific. The berries are light crimson in color and very large. Medium.

Brandywine. Large, roundish, conical, bright, glossy crimson berries, firm and solid; excellent quality and fine flavor. Medium.

Commonwealth. Large, glossy crimson berry, of excellent quality, a great cropper and one of the latest.

Gibson. Very large, deep red, fine flavor. Medium.

Glen Mary. Very large, highly colored, firm, ranks with best in flavor. Medium to late.

Golden Gate. New seedling, resembles the Marshall and will succeed where the Marshall fails. It produces strictly fancy, firm fruit clear to the end of the season, of a rich crimson color.

Howard 17. This is undoubtedly one of the finest early Strawberries; fruit is of attractive conical form, bright red in color, and of delicious, mildly acid flavor.

Judith. A large, medium-red, pointed berry; a good market variety; very early.

Marshall. Large, rich crimson, and fine flavor. One of the most popular sorts. Medium.

Premier. One of the best of the extra early varieties; does well in almost any section; excellent quality; bright red.

Senator Dunlap. Dark red berries of medium size. The flesh is red all through, and exceedingly juicy. Early midseason.

Warren. Dark blood red, 'extra size, broad and flattened at tips, borne in large clusters. Medium.

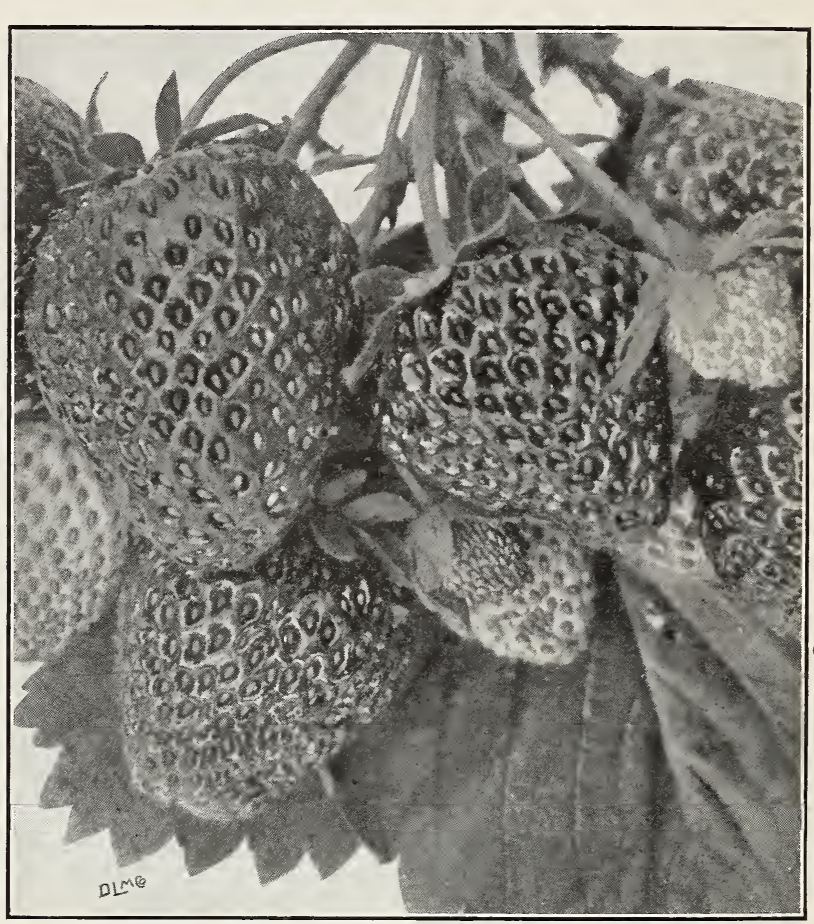

\section{Everbearing Strawberries}

$\$ 8.00$ per $100, \$ 75.00$ per 1000 .

Progressive. Considered one of the best perpetualbearing Strawberries. The fruit is rich and sweet, a deep red inside and out; of good medium size and quite firm.

Superb. Perfect blossoms. Enormous crops in June, and in September same plants are filled with fruit. It does not fruit on new runners. The berries are large and a rich, dark red.

\section{Fruit TREes}

Our collection comprises all the best and most popular kinds.

Apples. 5 to $7 \mathrm{ft}$., $\$ 1.50$ each, $\$ 15.00$ per doz. Cherries. 5 to $7 \mathrm{ft}$., $\$ 1.75$ each, $\$ 18.00$ per doz. Pears. 5 to $7 \mathrm{ft}$., $\$ 1.50$ each, $\$ 15.00$ per doz.

Page twenty
Peaches. $3 / 4$-in. diameter, $\$ 1.00$ each, $\$ 10.00$ per doz. Plums. 5 to $7 \mathrm{ft}$., $\$ 1.75$ each, $\$ 18.00$ per doz.

Quinces. 3 to $4 \mathrm{ft}$., $\$ 1.50$ each, $\$ 15.00$ per doz. 
We especially recommend the following varieties:

Alice Tiplady. A soft burnt orange. The queen of the Primulinus type. Doz. $\$ 1.25,100 \$ 7.00$.

Halley. Very large, lovely salmon-pink; the lower petals have yellow blotch with carmine markings. Doz. 60c., $100 \$ 4.00$.

Jewel. One of the best in Primulinus type. Salmonpink with beautiful yellow throat. Doz. $\$ 2.00$.

Mrs. F. Pendleton. Fine large salmon-pink, with blood-red blotch at throat. Doz. 90c., $100 \$ 6.00$.

Mrs. Dr. Norton. A pure white with tips of petals La France pink. Finest variety of this type. Doz. $\$ 1.50$, $100 \$ 10.00$.
Prince of Wales. Beautiful early blooming salmon; fine for cuttings. Doz. $\$ 1.25,100 \$ 7.00$.

Souvenir. Tall-stemmed, deep yellow variety, four to six open at same time. Good keeper and early. Doz. $\$ 2.00$.

White Butterfly (New). Beautiful Kunderd variety. Pure white; butterfly form. Doz. $\$ 2.50$.

Scarlano. Dazzling scarlet-orange, with almost black markings in throat. One of the finest early reds. Doz. $\$ 1.50,100 \$ 10.00$.

Maidens Blush. Blush-pink, with finely formed flowers. Free flowering and very early. Doz. $\$ 1.25$, $100 \$ 7.00$.

We are headquarters for the International Harvester Co.'s line of McCormick-Deering Harvesting Machines, Tillage Implements, etc., including Binders, Cream Separators, Engines, Ensilage Cutters, Grinders, Harrows, Hay Loaders, Manure Spreaders, Mowers, Rakes, Tedders, Tractors. Sulky and Walking Plows, and repairs for same.

Also headquarters for Coldwell Motor, Horse and Hand Mowers, Townsend Triplex Horse and

Hand Mowers and Pennsylvania Golf and Hand Mowers.

Agents for the Hussey Plows, Cultivators and Stone Boats.

Agents for Iron Age Hand Cultivators and Seeders.

Agents for Columbian Tape-Marked Pure Manila Rope.

\section{Garden and Greenhouse Requisites, Miscellaneous Tools, Etc.}

Axes. Warranted steel. Witherell's extra quality, handled. $\$ 3.00$ to $\$ 3.50$.

Barrow, New England Garden. A strong, wellmade barrow.

No. 64 , Medium ....................\$8.50

No. 65, Large......................... 9.50

No. 4, Boys or Ladies................... 6.50

Baskets, Shepherd. 1 bus. $\$ 2.50 ; 2$ bus. $\$ 4.00$ each.

Baskets. For holding leaves. 4 bus. $\$ 6.00$ each.

Houchin's Dry Powder Bellows. $\$ 3.00$ to $\$ 4.00$ each.

Savage Jr. Powder Gun. For applying powdered insecticides. $\$ 1.50$ each.

Boxes for Cut Flowers. The following sizes are kept in stock. Others can be furnished promptly.

\begin{tabular}{|c|c|c|c|c|}
\hline Length & Width & Depth & Doz. & 100 \\
\hline 18 in. & 5 in. & & $\$ 1.00$ & $\$ 7.00$ \\
\hline $21 \mathrm{in.}$ & 5 in. & & . 1.10 & 7.50 \\
\hline $24 \mathrm{in.}$ & $5 \mathrm{in.}$ & $3 \frac{1}{2}$ in & 1.20 & 8.00 \\
\hline in. & $5 \mathrm{in}$. & $31 / 2$ in & 1.30 & 9.00 \\
\hline n. & $8 \mathrm{in}$. & 5 in & 1.40 & 9.50 \\
\hline in. & $8 \mathrm{in}$. & in & 1.50 & 10.50 \\
\hline & & & 1.75 & 13.00 \\
\hline & & in & 2.25 & 16.50 \\
\hline
\end{tabular}

Corrugated Shipping.

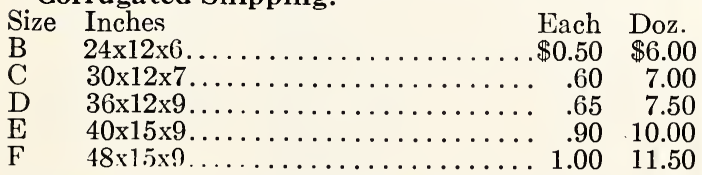

Brooms. For use in greenhouses, stables, etc. Two sizes. $\$ 1.25$ and $\$ 1.50$ each.

Brushes, Pole. Complete with bracket to attach to pole for using creosote in high places. $\$ 1.25$ each.

Brushes and Can. For creosote. The can fastens to the belt, leaving the hands free. $75 \mathrm{c}$. each.
Burlap. For putting around trees to trap gypsy moths. 8 in. wide, 8c. per yd.; 100 yds. $\$ 7.50 ; 40$ in. wide, 22c. per yd.; piece about $100 \mathrm{yds}, 20 \mathrm{c}$. per yd.

Burning Brands. For marking tools, etc. Six letters or less, $\$ 6.00$; each additional letter, $\$ 1.00$.

Bush Hooks. Strapped-eye handle. $\$ 2.00$.

Carnation Support, Excelsior. Heavy galvanized wire. In two sizes. 13 in., $\$ 3.00$ per $100 ; 20$ in., $\$ 3.50$ per 100 . One of each length makes a complete plant support.

Cotton Wadding. In large sheets, for protecting plants and flowers from frost. $10 \mathrm{c}$. each, $\$ 1.10$ per doz., $\$ 8.00$ per 100 .

Bulb and Seed Pans, Round.

Size Each Doz. Size Each Doz. 6 in....... $\$ 0.15 \$ 1.50 \mid 10$ in...... $\$ 0.75 \$ 7.00$

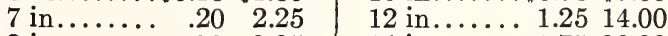

$\begin{array}{llllll}8 \text { in......... } & .30 & 3.25 & 14 \text { in........ } & 1.75 & 20.00\end{array}$

9 in ......... .50 $5.50 \quad 16$ in....... 2.7525 .00

Flower Pots, Standard. Measurement from inside to inside. Width and depth equal.

Size Doz. 100 Size Doz. 100

2 in....... \$0.20 $\$ 1.40 \mid 6$ in..... $\$ 1.40 \$ 10.00$

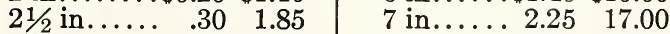

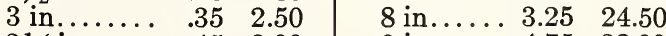

$\begin{array}{llll}31 / 2 \text { in...... } & .45 & 3.00 & 9\end{array}$

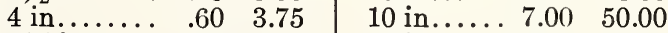

$41 / 2$ in...... $\quad .75 \quad 5.00 \quad 11$ in...... $10.00 \quad 75.00$

$\begin{array}{lllll}5 \text { in......... } & .90 & 6.75 & 12 \text { in.......14.00 } 100.00\end{array}$

Flower Pot Saucers, Lacquer Waterproof
$\begin{array}{lll}\text { Size } & \text { Each Doz. } \\ 4 \text { in } \ldots \ldots \ldots . . . & \$ 0.07 & \$ 0.75\end{array}$

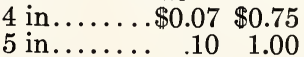
6 in........... $.15 \quad 1.50$
7 in........ $\quad .20 \quad 2.00$
8 in........ $.25 \quad 2.50$
9 in........ $\quad .30 \quad 3.25$
Size Each Doz.
10 in ..... \$0.40 \$4.25
11 in...... $\quad .45 \quad 5.25$
12 in...... $\quad .65 \quad 7.00$
13 in..... . .75 8.50
14 in...... $1.00 \quad 10.00$
$\begin{array}{llll}16 & \text { in....... } & 1.50 \quad 16.00\end{array}$ 
GARDEN AND GREENHOUSE REQUISITES

Flower Pot Hanger, Krick's Perfect. No. 1 will fit from $31 / 2$ - to 5 -in. pots, 40 c. per doz. No. 2 will fit from 5- to 8-in. pots, 45c. per doz.; No. 3 will fit from 8- to 12-in. pots, 50c. per doz.

Flower Vases, Galvanized Iron. Strong, light, durable, made of good material with heavy hoop at base of can to reinforce bottom of vase. These vases are finished in a moss green enamel baked on. No. Top Diam. Bot. Diam. Hght. Each Doz. $5 \quad 73 / 8$ in. $51 / 2$ in. 11 in. ....\$1.25 $\$ 13.50$ $6 \quad 73 / 8$ in. $\quad 5 \frac{1}{2}$ in. $\quad 17$ in..... 1.5016 .00 78 in. $6 \frac{1}{4}$ in. 11 in..... 1.2513 .50 89 in. $\quad 7 \frac{3}{8}$ in. 12 in...... 1.5016 .00 99 in. $73 / 8$ in. 17 in...... 1.7518 .00 $1065 / 8$ in. 5 in. 14 in..... 1.2513 .50 $11 \quad 5 \frac{1}{2}$ in. $\quad 4 \frac{1}{2}$ in. $\quad 15$ in..... 1.2513 .50 125 in. 4 in. $91 / 2$ in..... 1.0011 .00

Glass Cutters. 25c. and 50c. each.

Gloves, Gardeners' Pruning. With gauntlets, $\$ 3.00$ per pair; without gauntlets, $\$ 2.00$ per pair.

Glaziers' Points (Perfection). Will stop glass from slipping. Made of steel wire, galvanized. Double point. Per box of 1000 , No. 2, 85c.; No. 21/2, 90c.

Glaziers' Points (Zinc City). Made of zinc. Will not rust. In three sizes, $5 / 8,3 / 4$ and $7 / 8$ inches long. Fach size $75 \mathrm{c}$. per lb.

Hose, Rubber, Dreadnaught. Cannot separate between the plies, and does not kink. Made in continuous lengths up to $500 \mathrm{ft}$. $1 / 2 \mathrm{in}$. in 25 - or $50-\mathrm{ft}$. lengths, at $22 \mathrm{c}$. per ft.; $3 / 4$ in. in 25 - or 50 -ft. lengths, at $25 \mathrm{c}$. per ft.

Labels, Copper. Made of copper and copper wired, indestructible and always legible. No. $1,31 / 2 \mathrm{x}^{3} / 4$ in., $\$ 2.25$ per 100 ; No. $2,5 \times 11 / 8$ in., $\$ 2.75$ per 100 .

Labels, Wood. For plants and trees. Plain and Painted Plain

$\begin{array}{rrrr} & 100 & 1000 & 1000 \\ 4 \text { in. Pot Label......... } \$ 0.25 & \$ 1.50 & \$ 1.90 \\ 5 \text { in. Pot Label......... } & .30 & 2.00 & 2.50 \\ 6 \text { in. Pot Label......... } & .35 & 2.25 & 3.00 \\ 8 \text { in. Garden Label...... } & .90 & 6.50 & 8.00 \\ 10 \text { in. Garden Label...... } & 1.15 & 8.25 & 10.50 \\ 12 \text { in. Garden Label...... } & 1.50 & 10.50 & 13.00 \\ 31 / 2 \text { in. Tree Label....... } & .25 & 1.25 & 1.75 \\ 31 / 2 \text { in. Tree, iron wired. . } & .30 & 2.00 & 2.50 \\ 31 / 2 \text { in. Tree, copper wired } & .35 & 2.50 & 3.00\end{array}$

Mats, Hotbed. Made by hand of the best rye straw. Size $6 \times 6$ ft., $\$ 3.50$ each.

Mats, Hotbed. $76 \times 76$ in. Made of drilling filled with wool and quilted. \$5.50 each.

Paper, Green Waxed. Sheets $12 \times 18$ in. Lb. $75 \mathrm{c}$.

Paper, White Tissue. Sheets 20x30 in. Lb. 50c., ream, about 7 lbs. $\$ 2.75 ; 24 \times 36$ in., lb. 50 c.

Paper, White, Waxed. Sheets $14 \times 18$ in. Lb. $50 \mathrm{c}$. Ream, about 6 lbs. $\$ 2.00$. Sheets, $24 \times 36$ in., lb. 50 c.

Paper, White, Wrapping. Sheets, $24 \times 36$ in. Lb. 22c. Ream, about 40 lbs., 20c. per lb.

Pencils, Indelible, Lead. With point protector. Black or blue, 20c. each.

Pruner, Standard Tree. Operated by a lever, to which the blade is connected by iron rod, 6- $\mathrm{ft}$. pole $\$ 1.75,8$-ft. pole $\$ 2.00,10$-ft. pole $\$ 2.25$, 12 -ft. pole $\$ 2.50$, 14-ft. pole $\$ 2.75,16$-ft. pole $\$ 3.00$ each. Extra blades, 25c. each.
Pruner, Telephone Tree. Without pole (see cut). A pole of any length to suit requirements can be inserted in the socket. It is operated by a cord tied in the end of the lever. $\$ 1.50$ each.

Extra blades 25c. each.

Extra springs 25c. each.

Plant Tubs, Cedar.

For ferns, palms and other large plants Made of thick cedar, nicely painted green.Drop handles. No 2 and larger have hook handles. Outside measurements:

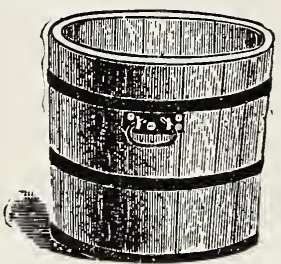

\begin{tabular}{|c|c|c|c|}
\hline No. & $\begin{array}{c}\text { Diam. } \\
\text { across top }\end{array}$ & $\begin{array}{l}\text { Height } \\
\text { outside }\end{array}$ & Each \\
\hline 1 & 28 in. & 22 in. &.$\$ 16.50$ \\
\hline 2 & in. & 20 in. & . 13.50 \\
\hline 3 & in. & $181 / 2$ in. & 8.75 \\
\hline 4 & in. & 17 in. & 7.00 \\
\hline 5 & in. & in. & 5.75 \\
\hline 6 & $181 / 2 \mathrm{in}$. & 15 & 4.50 \\
\hline 7 & 17 in. & 14 & 4.00 \\
\hline 8 & in. & 13 & 3.50 \\
\hline 9 & 14 in. & 12 in. & 2.75 \\
\hline 10 & 12 in. & $91 / 2$ in & 2.25 \\
\hline 11 & $101 / 2$ in. & 9 in & 2.00 \\
\hline 12 & $91 / 2 \mathrm{in}$. & 8 & 1.50 \\
\hline 13 & 8 in. & 7 & 1.25 \\
\hline
\end{tabular}

Tubs, Richmond Cedar. Strongly made of selected white cedar and bound with electric-welded wire; painted green. Without handles.

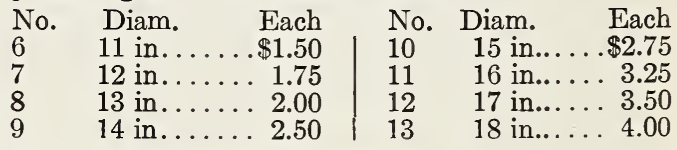

\section{Pump Auto Spray.} An efficient compressed air sprayer for all-round use. Each pump is equipped with $2 \mathrm{ft}$. of $1 / 2$-in. 5-ply hose, clog-proof automatic shut-off nozzle; $2 \mathrm{ft}$. brass extension rod. Full instructions, illustrated list of repair parts and spray calender.

No. 1B, 4-gal. brass tank, price $\$ 10.00$.

No. 1 D, 4 -gal. galv. tank, price $\$ 7.00$.

No. 50D, 21/2-gal. galv. tank, price $\$ 6.00$.

No. 50B, $2 \frac{1}{2}$ gal. brass tank, price $\$ 8.50$.

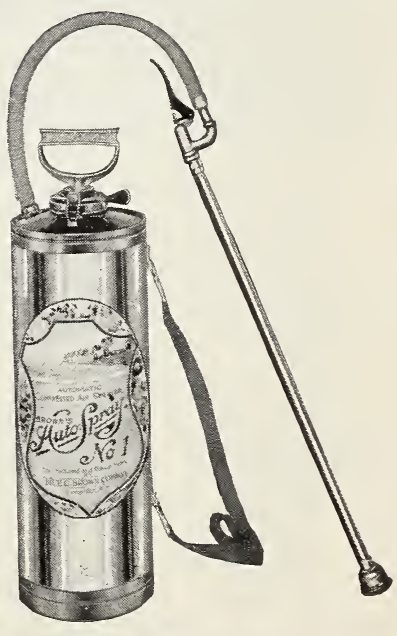

Brass strainer for same, price $\$ 1.25$.

Brass elbow for same, price 35c.

Pump, Kinney's Atomizer. For use in greenhouses to distribute liquid fertilizer or to mix or temper hot and cold water under pressure. $\$ 2.50$ each. 


\section{GARDEN AND GREENHOUSE REQUISITES,}

Pump, Auto Spray No. 5. Made entirely of brass, with two ball valves that can be instantly cleaned, it is double acting and throws a continuous spray. Excels all hand pumps.

Complete with pump, hose, nozzle and strainer.\$5.00 Galvanized iron knapsack tank with carrying

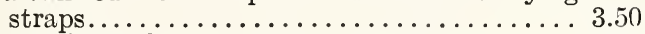

Extension rod.................. .50 Pump and knapsack compl., with extension rod. 9.00

Pump, Auto Spray No. 60. Double-acting, high pressure, bucket pump with air chamber. Price \$6.00.

Pump "Auto Spray." Wheelbarrow type. For use in garden, greenhouse or orchard it is especially adapted. Also used for whitewashing. It has a galvanized steel tank, steel truck and wheel, brass plunger head, cylinder and valves. Perfect agitation. No. 3D, 12-gal. complete, price $\$ 23.50$.

Putty Bulb. For glazing greenhouse sash. $\$ 1.50$ each. By mail $\$ 1.60$.

Putty, Twemlow's Old English Glazing. A superior article for bedding glass in sash or filling cracks or seams in roof joints, etc. 1 gal., 3 gal. and 5 gal. containers at $\$ 3.75$ per gal.

Raffia. The best material for tying. Soft, pliable and strong. 40c. per lb.

Raffia, Green. For tying plants, etc. $\$ 1.50$ per lb.

Rakes, Gibbs' Lawn. All steel; reversible, strong and light, 24 teeth, \$1.00 each.

Rakes, Hay, Wood. Extra quality, three bow, $\$ 1.10$.

Rakes, Lawn, Wood. Three bow, bent handle, with close teeth. $\$ 1.25$ each.

Rakes, Steel Garden. Long teeth. 10 teeth, $\$ 1.00$; 12 teeth, $\$ 1.10 ; 14$ teeth, $\$ 1.20 ; 16$ teeth, $\$ 1.25$; 18 teeth, $\$ 1.35$ each.

Rakes, Steel Lawn. Short teeth. 12 teeth, $\$ 1.25 ; 14$ teeth, \$1.35; 16 teeth, $\$ 1.50$ each.

Sash, Hotbed. Well made from thoroughly seasoned lumber, and glazed with double thick glass. Frame $13 / 4$ in., $3 \times 6 \mathrm{ft}$., $\$ 9.50$ each. Crating extra at cost.

Saws, Cross-cut, Disston's. Champion tooth, filed and set ready for use with handles. $41 / 2 \mathrm{ft}$. $\$ 4.50$, $5 \mathrm{ft}$. $\$ 5.00,51 / 2 \mathrm{ft}$. $\$ 5.50,6 \mathrm{ft}$. $\$ 6.00$ each.

Saws, Cross-cut, One-Man. Champion tooth. With supplementary handles. $3 \mathrm{ft}$. $\$ 3.50,31 / 2 \mathrm{ft}$. $\$ 4.00,4$ ft. $\$ 4.50$ each.

Saws, Hand. Extra refined spring steel. 22 in. $\$ 3.00$, 24 in. $\$ 3.25,26$ in. $\$ 3.50$ each.

Saws, Pole Pruning. $\$ 2.00$ to $\$ 2.50$.

Saws, Pruning. Single and double edge. Extra refined spring steel. 18 in. $\$ 1.75,20$ in. $\$ 2.00$ each.

Sieves, Wire. For sifting loam, gravel, etc. Strong and well made. Any size of mesh can be furnished. From 16 to 20 in. diameter. $\$ 2.00$ to $\$ 3.00$ each.

Silkaline (Smilax Thread). Spools 40c. each; per box of 8 spools, $\$ 3.00$.

Shears, Clyde Draw-Cut. The best and strongest lopping shears made. Cuts without crushing. No. 1 , \$3.25; No. 2, \$3.50.

Shears, Hedge or Grass. English, pruning notch. 8-in. blade, $\$ 4.00 ; 9$-in. $\$ 4.50$, 10 -in. $\$ 5.00$ each.

Shears, Twin Works Pruning. 8-in. $\$ 2.75,9$-in. $\$ 3.00$. 10-in. $\$ 3.50$.
Shears, Pruning, French. With wheel spring, polished. 7 -in. $\$ 2.25,8$-in. $\$ 2.50,9$-in. $\$ 3.00,10$-in. $\$ 3.50$. Extra springs, 50c. each.

Shears, Ladies' Pruning. Nickel plated. 6-in. \$2.00.

Shovels, Snow. Wood. Malleable iron tip, \$1.25.

Shovels, Snow. Steel, either long or D-handle, $\$ 1.00$.

Scythes, "Witherell's." Finest Cutlery Steel. Fully warranted. $\$ 2.00$ each

Scythes, Broad English, or Lawn. $\$ 3.00$ each.

Scythes, Heavy Bush. $\$ 2.25$ each.

Scythes, Weed or Bramble. $\$ 2.25$ each.

Scythe Snaths. $\$ 1.75$ each; Bush, $\$ 2.00$ each.

Scythe Stones. Carborundum. 50c. each.

Scythe Stones. English Round. Talacre. 50c. each.

Scythe Stones. "Manchester.' 25c. each.

Seed Sower, "Cahoon." Best machine for sowing broadcast, grass seed, oats, barley, etc. $\$ 6.00$ each.

Seeder, Wheelbarrow, Grass. This seeder is arranged to sow all kinds of grass seed, etc., in any quantity, from 6 to 40 qts. to acre. Price, with 14-in. hopper, $\$ 15.00$ each.

Sprayer and Atomizer, Compressed Air. Makes a continuous fog-like spray which can be delivered at any angle. 1 qt. brass tank, $\$ 1.25 ; 2$-qt. brass tank $\$ 2.00$.

Sprayer, Vapor. Nickel plated and mounted in a bottle, excellent for house use. $\$ 1.50$ each.

Stake Fasteners, Eureka. For holding the wire to rose stakes. Box of $1000, \$ 3.00$.

Stakes, Japanese Bamboo Garden. Very strong and durable, $5 / 8$ to $3 / 4$ in. in diameter. $4 \mathrm{ft}$. $75 \mathrm{c}$. per doz., $\$ 6.00$ per $100 ; 6$ ft. $\$ 1.00$ per doz.; $\$ 7.00$ per 100 ; 8 ft. $\$ 1.25$ per doz., $\$ 8.00$ per 100 .

Stakes, Japanese Cane, Green. Small and inconspicuous, but strong and useful for plants.
Ft. Doz. 1001000
$1 \ldots \ldots \$ 0.10 \$ 0.75 \$ 6.00$
$\begin{array}{llll}11 / 2 \ldots & .12 & .85 & 7.00\end{array}$
$\begin{array}{llll}1 \ldots \ldots & .15 & 1.00 & 9.00\end{array}$
Ft. Doz. 1001000
$3 \$ 0.20 \$ 1.50 \$ 13.00$
$\begin{array}{llll}31 / 2 . & .25 & 1.75 & 15.00\end{array}$
$21 / 2 \cdots \quad .18 \quad 1.3511 .50$
$\begin{array}{llll}4 \ldots . . & .30 & 2.00 & 18.50\end{array}$
$\begin{array}{llll}5 \ldots . . & .35 & 2.50 & 23.00\end{array}$

$6 \mathrm{ft}$., Plain, 40c. per doz., $\$ 3.00$ per $100, \$ 28.00$ per 1000 . $8 \mathrm{ft}$., Plain, 50c. per doz., $\$ 4.00$ per 100, $\$ 37.00$ per 1000 .

Stakes, Galvanized Wire Rose.
Ft. $\quad 1001000$
$3 \ldots \ldots \ldots \$ 3.00 \$ 25.00$
$31 / 2 \ldots \ldots 3.50 \quad 30.00$
$4 \ldots \ldots \ldots 4.00 \quad 35.00$
Ft.
$41 / 2 \ldots \ldots \$ 4.50 \$ 40.00$
$5 \ldots \ldots \ldots 5.00 \quad 45.00$
$6 \ldots \ldots \ldots 6.00 \quad 55.00$

Stakes, Square, Unpainted. Hardwood. 1001000 27 in. long...............\$ \$0.75 \$5.00

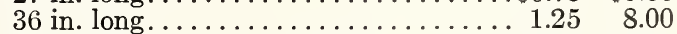

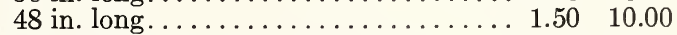

Sticks, Match. Pine, 5-32 in. thick. Green, 60c. per $100, \$ 4.50$ per 1000 .

Thermometers, Self-Registering. Oxidized metal scale. Max. and min., 10 in., $\$ 6.00$ each.

Wilder's. Japanned tin case, convex scale. 6 in. 75 c., 8 in. $\$ 1.00,10$ in. $\$ 1.25$.

Wilder's. Japanned tin case; heavy. 8 in. $\$ 1.25$, 10 in. $\$ 1.50,12$ in. $\$ 1.75$.

Wilder's Hotbed. Boxwood, brass-tipped. $\$ 3.50$.

Tinfoil. For bouquets, etc. 40c. per lb.; violet foil, 75c. per $1 \mathrm{~b}$. 


\section{GARDEN AND GREENHOUSE REQUISITES, MISCELLANEOUS TOOLS, ETC.-Continued}

Tree Scrapers. Best steel, $\$ 1.25$ each.

Twine, Green Linen. For Smilax. 50c. per ball.

Twine, Green Cotton. 25c. per ball, $\$ 2.50$ per doz.

Twine, Hard. For tying parcels. Heavy, medium, and light. 50c. per ball, $\$ 5.50$ per doz.

Twine, Soft. 35c. per ball, $\$ 3.50$ per doz.

Twine, Tarred Marline. Twisted. In 5-lb. and 10lb. balls. Each 55c. per lb.

Twine, Tarred Yarn (Lathyarn). Excellent for tying shrubs, etc. 30c. per lb.

Twine, White Cotton. 25c. per ball, $\$ 2.50$ per doz.

Twine, Yacht Marline. In $1 / 2 \mathrm{lb}$. balls, 50c. each.

Trowels, Flat Steel. Best steel, carefully tempered. 6 in., \$1.25; 7 in., \$1.50 each.

Trowels, Garden. Extra forged steel. Solid steel blade and shank. 6 in., $65 \mathrm{c} . ; 7$ in., $75 \mathrm{c}$. each.

Trowels, Garden, English Genuine. Extra heavy. 6 in., $\$ 1.00 ; 7$ in., $\$ 1.25$.

Trowels, Transplanting. 6 in., 25c. each.
Watering Pots, English. An ideal pot for watering seedlings, cuttings, etc. 3 qt., $\$ 6.00 ; 4$ qt., $\$ 7.00$; 6 qt., $\$ 8.00 ; 8$ qt., $\$ 9.00 ; 10$ qt., $\$ 10.00$ each.

Watering Pots, French. Made of galvanized iron; oval in shape, with brass handle and long spout; one fine and one coarse copper-faced rose with each. 6 qt., $\$ 6.50 ; 8$ qt., $\$ 7.00 ; 10$ qt., $\$ 7.50 ; 12$ qt., $\$ 8.00$ each.

Watering Pots, Galvanized Iron. The best watering pot made, for strength, durability and neatness. Made from best quality iron. A coarse and fine copper-faced rose with each pot.

4 qts., spout 18 in. long. . . . . . . . . . . . \$5.00

6 qts., spout 21 in. long. ................ 5.50

8 qts., spout 23 in. long. . . . . . . . . . . . . 6.00

10 qts., spout 25 in. long. . . . . . . . . . . . 6.50

12 qts., spout 25 in. long. . . . . . . . . . 7.00

Wire. Annealed galvanized. No. $14 \$ 1.75$, No. $16 \$ 2.00$, No. $18 \$ 2.25$, No. $20 \$ 2.50$ per stone of 12 lbs. in coils.

\section{FERTILIZERS}

Acid Phosphate. 16 per cent. soluble and available phosphoric acid. 100 -lb. bag $\$ 2.50$, ton $\$ 38.00$.

Ashes, Unleached Hardwood. As a fertilizer for lawns, gardens and fruits, hardwood ashes are unequaled; they are not a mere stimulant, but supply natural plant food, permanently enriching the soil. High in potash. In bags, per 100 lbs. $\$ 3.00$, per ton $\$ 50.00$.

Bon Arbor. Immediately soluble in water. A com-

plete plant food. containing nitrogen, potash and phosphoric acid in sufficient quantities. 1-lb. pkg. 60c., 5 lbs. $\$ 2.50$.

Bone, Crushed or Inch. Especially valuable for Grape borders. Per 100 lbs. $\$ 7.50$.

Bone, Coarse or Cracked. Ground coarse for Grape borders or poultry. 100 lbs. $\$ 7.50$.

Bone, Fine Ground (Bone Meal). One of the best fertilizers for general purposes. 10 lbs. $75 \mathrm{c} ., 25 \mathrm{lbs}$. $\$ 1.50,50$ lbs. $\$ 2.25,100$ lbs. $\$ 3.75$, ton $\$ 158.00$.

Bone, Special Raw, Fine Ground. Ground specially for our trade from pure raw bone. 100-lb. bag, $\$ 7.50$.

Charcoal. Coarse and fine. 10 lbs. 75 c., 100 lbs. $\$ 5.00$.

Clay's Fertilizer. This valuable imported manure is especially recommended to all who grow either fruit, flowers or vegetables and wish to bring them to the highest perfection. 14 lbs. $\$ 2.25 ; 28$ lbs. $\$ 4.25$; 56 lbs. $\$ 8.00 ; 112$ lbs. $\$ 15.00$.

Chrysanthemum Manure, Thomson's Special. Entirely soluble and very powerful, especially suit- able for top dressing Chrysanthemum and similar plants. 7 lbs. $\$ 1.75,14$ lbs. $\$ 2.75,28$ lbs. $\$ 4.50$, 56 lbs. $\$ 8.00$.

Lime, Agricultural. An unusually pure calcium lime, especially prepared for use on the soil. Shipped in the form of a dry powder. $100 \mathrm{lbs}$. $\$ 1.50,500 \mathrm{lbs}$. $\$ 7.00$, ton $\$ 22.00$.

Nitrate of Soda. 95 to 98 per cent purity. $10 \mathrm{lbs}$. $\$ 1.00,25$ lbs. $\$ 2.00,50$ lbs. $\$ 3.00,100$ lbs. $\$ 5.50$.

Salt. Top dressing for lawns and Asparagus beds. Bag, about 140 lbs. $\$ 2.50$.

Sheep Manure, Pulverized, "Special Brand." This brand has no objectionable odor; it is a pure natural manure, and the most nutritious food for plants. Its effect is immediate, much more lasting and healthy than Guano or any other manure. It is the best of all manures for mixing with the soil for greenhouse plants. It makes the richest, safest and quickest liquid manure without any deleterious effects. Minimum guarantee, 21/4\% Ammonia, 11/2\% Phosphoric Acid, $11 / 4 \%$ Water Soluble Potash. 5 lbs. 35c., 10-1b. pkg. 60c., 25 lbs. $\$ 1.00,50$ lbs. $\$ 1.75$, 100 lbs. $\$ 3.25$, ton $\$ 55.00$.

Soot, Imported Scotch. Prevents mildew when mixed with sulphur at the rate of one-third sulphur and two-thirds soot; also a good fertilizer. Sold only in original bags of about 100 lbs. at $7 \mathrm{c}$. per lb.

Vine, Plant and Vegetable Manure, Thomson's. A safe and reliable food and stimulant for every fruitbearing plant, also for foliage, flowering plants and vegetables. $1 / 8$ cwt. (14 lbs.) $\$ 2.25,1 / 4$ cwt. (28 lbs.) $\$ 4.25,1 / 2$ cwt. (56 lbs.) $\$ 8.00,1$ cwt. (112 lbs.) $\$ 15.00$.

\section{INSECTICIDES and FUNGICIDES}

A Grade Cyanogas. Will destroy ants, rats, ground hogs, etc. Lb. can 75c.

Aphine. For the destruction of the green, black and white fly, thrips, red spider, mealy bug, caterpillars, scale, etc. Qt. $\$ 1.25$, gal. $\$ 3.50$.

Black Leaf 40 (Nicotine Sulphate). Highly recommended by spraying experts for destroying all suckling and many chewing insects. 1 oz. 35c., $1 / 2$ lb. $\$ 1.25,2$ lbs. $\$ 3.25,10$ lbs. $\$ 11.85$.

Carbola. A disinfectant used instead of whitewash. 5 lbs. 75 c., 10 lbs. $\$ 1.25,50$ lbs. $\$ 5.00$.

Copper, Ammoniated Solution of. A liquid fungicide, ready for use. Dilute at the rate of $1 \mathrm{qt}$. to 25 gals. of water, and spray lightly. (it. $\$ 1.50$, gal. $\$ 4.00$.

Creosote, Gypsy Moth. For the destruction of the eggs of gypsy moth. Qt. 50c., gal. \$1.25, 5 gals. $\$ 5.00$. 


\section{INSECTICIDES AND FUNGICIDES-Continued}

Cyanogas (Calcium Cyanide). "Grade G." For greenhouse fumigation, garden insects and other pests. Lb. 75 c., 5 lbs. $\$ 3.00,25$ lbs. $\$ 10.00$. "A poison," cannot send by mail.

Derrisol. A safe, non-poisonous, contact insecticide for the control of aphides or plant lice, red spider, green fly and many other soft-bodied sucking insects. Inexpensive and effective. Oz. 35c., $1 / 2 \mathrm{lb}$. $\$ 1.20$, lb. $\$ 2.00,2$ lbs. $\$ 3.00,10$ lbs. $\$ 12.00$.

Fungine. An infallible remedy for mildew, rust, wilt, bench rot and other blights. 1 gal. makes 50 gals. spraying material. Pt. 75c., qt. $\$ 1.25$, gal. $\$ 3.50$.

Herbicide Weed Exterminator. 1 qt. 75c., 1 gal. $\$ 2.00,5$ gals. $\$ 7.50,10$ gals. $\$ 12.50$.

Lemon Oil. A cheap, safe and effectual insecticide, for all insects and soft scale, highly recommended for house plants. Dilute with water 30 to 50 parts. $1 / 2$ pt. 40 c., pt. 75 c., qt. $\$ 1.25,2$ qts. $\$ 2.25$, gal. $\$ 4.00$.

Lime-Sulphur Solution. Will completely destroy San José and other scale. Qt. 50c., gal. $\$ 1.00,5$ gals. $\$ 3.50,10$ gals. $\$ 6.50,1 / 2$ barrel, about 30 gals. 35 c. per gal., 50-gal. barrels, 30c. per gal.

Lime and Sulphur (Dry). 1 lb. 35c., 5 lbs. $\$ 1.50$, 25 lbs. $\$ 4.50$.

Nico-Fume Tobacco Paper (Registered). For fumigating greenhouses. Positively the strongest Tobacco Paper on the market. In special friction-top tins sold as follows: 24 sheets, $\$ 1.25 ; 144$ sheets, $\$ 5.25 ; 288$ sheets, $\$ 9.50$.

Nico-Fume Liquid. A nicotine solution of exceptional purity. Does not stain or injure blooms or leave a disagreeable odor. $1 / 4 \mathrm{lb}$. $75 \mathrm{c}$., lb. $\$ 2.00$, 4 lbs. $\$ 7.00,8$ lbs. $\$ 13.00$.

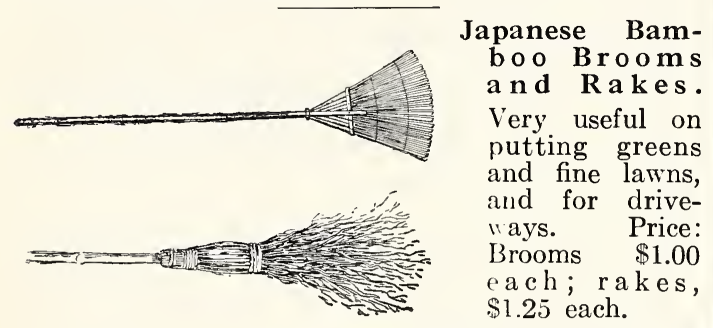

Richard's X-L-All, Liquid Insecticide. Destroys mealy bug, red spider, etc. Pt. $\$ 1.50$, qt. $\$ 3.00$, $1 / 2$ gal. $\$ 5.50$, gal. $\$ 10.50$.

Scalecide with Fungicide. For destroying San José scale and all other scale and soft-bodied sucking insects. Also all fungous diseases. Qt. 75c., gal. $\$ 1.85,5$ gals. $\$ 7.00,10$ gals. $\$ 12.00,30$ gals. $\$ 28.00$, 50 -gal. barrels, $\$ 40.00$.

Slug Shot, Hammond's. Destroys insects injurious to house and garden plants, vegetables and fruit of all kinds. Directions for use on each package. 5-lb. pkg. $75 \mathrm{c}$.

Sulphur Flour. Useful for fumigating, spraying mixtures, lice on plants or animals. Prevents mildew on Grape vines, bushes, etc. Lb. 12c., 5 lbs. 50c., 10 lbs. 85c., 25 lbs. $\$ 2.00,100$ lbs. $\$ 7.50$.

Soap, Fish Oil. 1-lb. box, 40c.; 5-lb. box, \$1.50; $10-1 b$. box, $\$ 2.40$.

Soap Spray, "Imp." Specially recommended and very effective in killing white fly and red spider. Pt. 65 c., qt. $\$ 1.00$, gal. $\$ 3.00,5$ gals. $\$ 11.00,10$ gals. $\$ 19.00$.

Soap Sulpho Tobacco. A very effective insecticide for use on plants in the house or outside. 3-oz. cakes $10 \mathrm{c}$., $1 / 2-1 \mathrm{~b}$. cake $20 \mathrm{c}$. each.

Tobacco Dust. For Aphis, etc., on the foliage and around the roots. Lb. 12 c., 5 lbs. 50 c., 25 lbs. $\$ 2.25$, 50 lbs. $\$ 4.00,100$ lbs. $\$ 7.50$.

Tobacco Stems. Small quantities. Lb. 5c., large bales or cases, lb. $4 \mathrm{c}$.

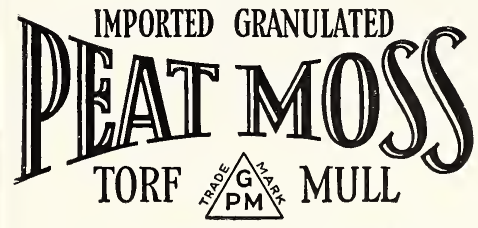

Peat Moss (Imported). Coarse and fine, $\$ 4.00$ per b a le. Trial bale, $\$ 1.50$ each.

PEAT, LEAFMOLD, ETC.

Silver Sand. For mixing with potting soil, etc. $\mathrm{Pk}$. $50 \mathrm{c}$. bu. $\$ 1.50$.

Leafmold. Best quality. Bag $\$ 3.50$.

Moss, Live Sphagnum. Bu. $\$ 1.50$, bag $\$ 3.50$.

Moss. Dry Sphagnum. Bag $\$ 1.50$, large bale $\$ 10.00$.

Orchid Peat, or Fern Root. Best selected hand picked. Bag $\$ 4.00$.

\section{CHOICE GRASS SEEDS}

Many growers of grass seeds offer several grades of each variety, varying greatly in price. We do not recommend nor do we sell the inferior grades. Those which we offer are strictly High Grade, and the prices at which we offer them should not be compared with those quoted for inferior grades.

Prices may change as the season advances. If to go by mail add Parcel Post rates to corer postage.

Awnless Brome Grass (Bromus inermis). Recommended for dry, arid soils where other grasses do not grow. In nutritive value is much inferior to many other sorts, but is very permanent and therefore useful for some locations.

Chewing's New Zealand Fescue. A splendid grass of creeping habit, forming a close and lasting turf; is a great drought resister, and thrives well on light, sandy soils. 24 lbs. per bus., 65c., per lb., $\$ 58.00$ per 100 lbs.

Greeping Bent (Agrostis stolonifera). One of the most valuable lawn grasses because of its short growth and deep green, fine-leaved foliage. Its stoloniferous roots form a strong, close, enduring turf, which is not injured by being frequently walked on. $\$ 1.25$ per lb.

Crested Dogstail (Cynosurus cristatus). Good for permanent pasture for sheep; is productive and early, suffers but little from dry weather, and is one of the best grasses for lawns; 35 lbs. to the acre. Lb. 85c., 100 lbs. $\$ 80.00$.

Hard Fescue (Festuca duriuscula). Admirable pasture grass of fine quality; thrives well in dry situations; 30 lbs. to the acre. Lb. 50c., 100 lbs. $\$ 45.00$. 


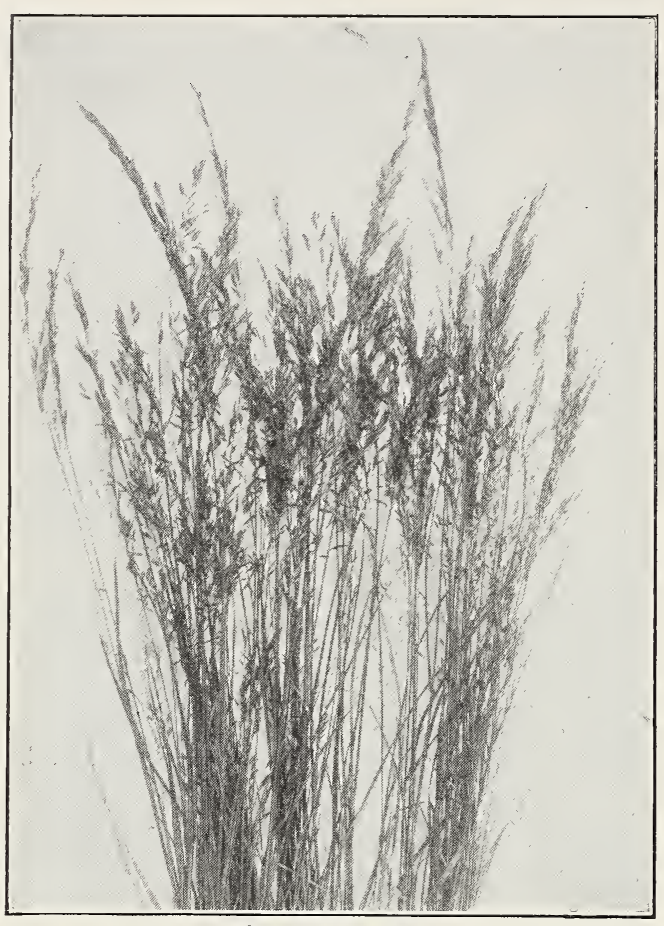

Meadow Fescue

Hungarian Grass. $\$ 5.00$ bus.

Italian Rye Grass (Lolium italicum). Thrives in any soil, yields an early and abundant crop, valuable for mixing with other pasture grasses; sow $50 \mathrm{lbs}$. per acre. Lb. 30c., 100 lbs. $\$ 25.00$.

Kentucky Blue (Poa pratensis). Also called "June Grass"; an early grass of much value; will do well upon any ordinary soil; stands the heat of Summer remarkably well. For pastures and lawns it has no superior, giving that peculiar, rich shade of bluish green so much admired in the best lawns; also making a very close, velvety turf. It is usually sown mixed with other fine grasses; when used alone, 30 to $40 \mathrm{lbs}$. per acre. Blossoms in June. Fancy clean seed. Lb. 45c., 100 lbs. $\$ 40.00$.

Lime Grass (Elymus arenarius). Has wide-spreading, thickly-matted roots which tend to hold drifting sands. Valuable for seashore and embankments. Cannot supply.

Meadow Fescue (Festuca pratensis). This is excellent for hay when sown with other grasses, such as Orchard grass and Timothy, and is also considered one of the best grasses for permanent pasture on a great variety of soils; sow 40 lbs. per acre. Lb. 40c., 100 lbs. $\$ 35.00$.

Meadow Foxtail (Alopecurus pratensis). One of the best and earliest of pasture grasses; thrives best in moist localities: 30 lbs. to the acre. Lb. $\$ 1.00$.
Orchard (Dactylis glomerata). One of the earliest grasses; yields immense crops and is excellent for pasture or hay; should be cut as it is coming into bloom, and will produce a heavy second crop; one of the best grasses. Sow 40 lbs. per acre. Lb. 35c. 100 lbs. $\$ 32.00$.

Perennial Rye Grass (Lolium perenne). A valuable grass for pastures or meadows, also very valuable where mixed with other grasses for lawns, golf links, etc. The seed is large and heavy, and produces a good growth in five or six weeks. It is also well suited to a variety of soils, and makes excellent hay when grown with Red Clover. We offer an extra choice lot of seed. Lb. 30c., 100 lbs. $\$ 25.00$.

Red Top (Agrostis vulgaris). A valuable native permanent grass, growing in almost any soil, moist or dry, but pays well for high cultivation; 14 to 16 lbs. per bus. Sow 40 lbs. per acre, if alone. Lb. 30c., 100 lbs. $\$ 25.00$.

Red Top, Fancy. Clean seed. Absolutely clean and free from chaff; 36 lbs. per bus. Lb. $40 \mathrm{c}$., $100 \mathrm{lbs}$. $\$ 36.00$.

Red or Creeping Fescue (Festuca rubra). A creeping rooted grass forming a close and lasting turf. Is especially adapted to dry and sandy soils, resists extreme drought, and is useful for gravelly banks and exposed hillsides. It is also valuable for shaded locations. Lb. 75c., 100 lbs. $\$ 70.00$.

Rhode Island Bent (Agrostis canina). Resembles Red Top, but is of dwarfer habit. A fine, hardy, very compact grass; very permanent, readily forming a heavy sward; excellent for lawns. Sow 4 bus. per acre, if alone. $14 \mathrm{lbs}$. per bus. R. I. grown, lb. $\$ 2.00$.

Rough Stalked Meadow Grass (Poa trivialis). A thickly-matted, spreading rooted species, forming a firm, fine turf, especially adapted to the shaded parts of lawns. It thrives on moist, rich soils and in sheltered situations. Valuable for permanent pastures. 26 lbs. per bus. Lb. 85c.

Sheep Fescue (Festuca ovina). In grass mixtures for high or dry land this is especially valuable, as it thrives on poor, light or gravelly soils. It is very hardy, resisting heat and cold, and is useful in mixtures for fair greens. 16 lbs. per bus. Lb. $45 \mathrm{c}$., 100 lbs. $\$ 40.00$.

Slender Fescue (Festuca tenuifolia). A variety of Sheep Fescue, but with finer leaves. It will grow on dry, poor soils, and is useful in mixtures for dry banks and slopes. 22 lbs. per bus. $\$ 1.00$ per lb.

Timothy, "Herd's Grass" (Phleum pratense). One of the most valuable grasses and more generally used for hay than any other. It prefers a moist, loamy soil, not doing well on light soil. It is generally sown with Red Top and Red Clover, and makes the most valuable hay. 45 lbs. per bus. Present price, lb. 12c., 100 lbs. $\$ 10.00$.

Wood Meadow (Poa nemoralis). A variety specially suited for the shaded portions of lawns where other grasses do not grow. Very permanent and hardy, resisting extremes of heat and cold. The creeping roots make a strong, firm sod. 18 lbs. per bus. Lb. 85c. 
CHOICE GRASS SEEDS-Continued

\section{Special Mixtures for Permanent Hay \\ Sow $50 \mathrm{lbs}$. to acre.}

No. 1 for Cool, Moist Soils......... 50 lbs. $\$ 24.00$

No. 2 for High, Dry Soils .............50 lbs. 23.00

No. 3 for Wet Soils...............50 lbs. 24.00
Special Mixtures for Permanent Pastures Sow 50 lbs. to acre.

No. 4 for Cool, Moist Soils......... . 50 lbs. $\$ 23.00$ No. 5 for High, Dry Soils..............50 lbs. 24.00 No. 6 for Wet Soils................50 lbs. 24.00

\section{CLOVER SEEDS}

Prices subject to change with the market. Add Parcel Post rates if wanted by mail.

Alfalfa, or Lucerne (Medicago sativa). Seed can be sown in April and May in this latitude, and much later in the South. The land should be deeply ploughed and carefully prepared; 20 to $25 \mathrm{lbs}$. of seed per acre are required. Lb. 4 c., 100 lbs. $\$ 40.00$.

Alsike, or Swedish (Trifolium hybridum). Hardiest of all the Clovers and on rich, moist soil yields an enormous quantity of hay or pasturage. Valuable for sowing with Clovers or grasses, as it forms a thick bottom and increases yield of hay. Lb. 55c., 100 lbs. $\$ 50.00$.

Bokhara Clover (Melilotus alba). Valuable sort for soiling and for ensilage and bees. Grows from 3 to 5 feet high; sown in rich soil may be cut three times; lasts for years if cut before flowering. $15 \mathrm{lbs}$. to the acre. Lb. 25 c., 100 lbs. $\$ 20.00$.
Crimson Clover (Trifolium incarnatum). An annual variety, largely used in the South for feeding green and for hay. The yield in fodder is large, and after cutting, it at once commences growing again and continues until cut by frost. Sow in April or May; 20 lbs. to the acre. Not always hardy in New England. Lb. 30c., 100 lbs. $\$ 25.00$.

Red Clover, Medium (Trifolium pratense). The leading variety of clover for pastures or meadows. Requires deep, rich soil. Sow in Spring. Lb. 60c., 100 lbs. $\$ 555.00$.

Red Northern, or Mammoth. Grows 4 to $5 \mathrm{ft}$. high, and is used to plow under for manure. Lb. $60 \mathrm{c}$., $100 \mathrm{lbs} . \$ 55.00$.

White Dutch Clorer (Trifolium repens). The best variety for lawns, as it forms a close herbage and remains green throughout the season; valuable when mixed with grass seeds for pasture. Lb. 90c.

\section{SEED GRAIN, ETC. \\ Prices subject to change with the market.}

Great care is used in the selection of our seed grain. We endeavor to have each kind true to name and free from mixture and foul seeds. Samples and special quotations for large quantities sent on request.

BARLEY. Sow $1 \frac{1}{2}$ to 2 bus. per acre ( $48 \mathrm{lbs}$. per bus.)

Beardless. Bus. $\$ 2.75$.

Montana. Choice seed. Bus. $\$ 2.75$.

RYE. Sow $1 \frac{1}{2}$ bus. per acre. (56 lbs. per bus.)

Winter "Rosen." For Fall sowing. Bus. $\$ 3.00$.

WHEAT. Sow $1 \frac{1}{2}$ bus. per acre. (60 lbs. per bus.) Winter, Klondyke Bald. White grain. Bus. \$3.50. VETCHES, Sand, Winter, or Hairy (Vicia villosa). Thrives on poor, arid, sandy soil, and can be sown either in Spring or Fall. If cut as soon as full grown and before flowering a second growth will be made. Sow 40 to $50 \mathrm{lbs}$. per acre. Bus. of $60 \mathrm{lbs}$. $\$ 18.00$.

\section{MUSHROOM}

\section{(Champignon)}

$1 \mathrm{lb}$. of spawn is sufficient for 9 square feet of bed. If wanted by mail, add postage at Parcel Post rates.

American Pure Culture. Single bricks 30c. each, 20 bricks $\$ 5.00$.

American Pure Culture. New mammoth strain. Single bricks 40c. each, 20 bricks $\$ 7.00$.

\section{TOMATO}

\section{Special Varieties for Greenhouse}

Carter's Sunrise (True Stock). One of the best Tomato for indoor or outdoor cultivation. Perfect in shape, of good size and free cropper; the fruit is bright red. Pkt. 250., oz. $\$ 1.75$.

Crockford's Alaska, or "New Trellis." Without doubt the best forcing Tomato on the market. Also the best for outdoors if grown on trellises. Rich, deep color, solid flesh. Pkt. 50c.

Comet. One of the best for forcing; brilliant scarlet color: medium size, smooth and solid. Pkt. 25c., oz. $\$ 2.00$.
Lister's Prolific. This variety combines all the essential qualities of productiveness, size, flavor and color. Original pkt., 35̌c.

Lister's Protection. A new variety-the best of Lister's productions. Color dark crimson, a heavy cropper, perfect in shape and size. Pkt. $75 \mathrm{c}$.

LISTER'S EXCELSIOR. This variety is the result of a cross between Ailsa Craig and Lister's Prolific, one of the best for forcing. Original pkts. $35 \mathrm{c}$.

Stirling Castle. This is one of the best for indoor culture: Round, smooth, delicious flavor. Pkt. 25 c., $1 / 4$ oz. $\$ 1.00$, oz. $\$ 3.00$. 


\section{OILSKIN CLOTHING, ETC.}

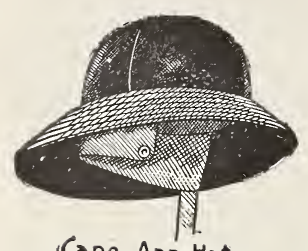

Cape Ann. Hot

When spraying with lime sulphur, arsenate of lead or other solutions, a waterproof suit is essential, to protect the flesh and clothes. Those we offer are especially designed for men who work at spraying or whose work takes them into wet places and who require light-weight, waterproof garments.

Oilskin Long Coats. Either yellow or black.... $\$ 6.50$ Oilskin Jackets. Either yellow or black....... 3.50 Oilskin Pants. Either yellow or black......... 3.50 Oilskin Hats (Pilot) Either yellow or black.......................... Waterproof Dressing for Oilskins, 75c. per can.

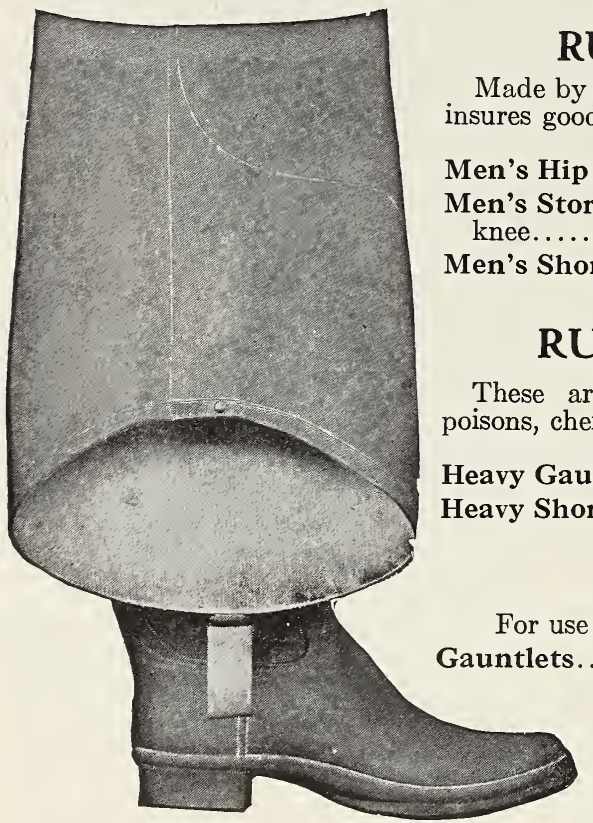

Rubber Boots

\section{RUBBER BOOTS}

Made by the Franklin Rubber Co., which insures goods of the finest quality.

Men's Hip Boots............... Per $\$ 9.00$

Men's Storm King. Comes just above

knee..................... 8.00

Men's Short Boots............. 7.00

\section{RUBBER GLOVES}

These are indispensable when handling poisons, chemicals, etc.

Heavy Gauntlet.

Per pair .. $\$ 4.25$

3.75

\section{LEATHER GLOVES}

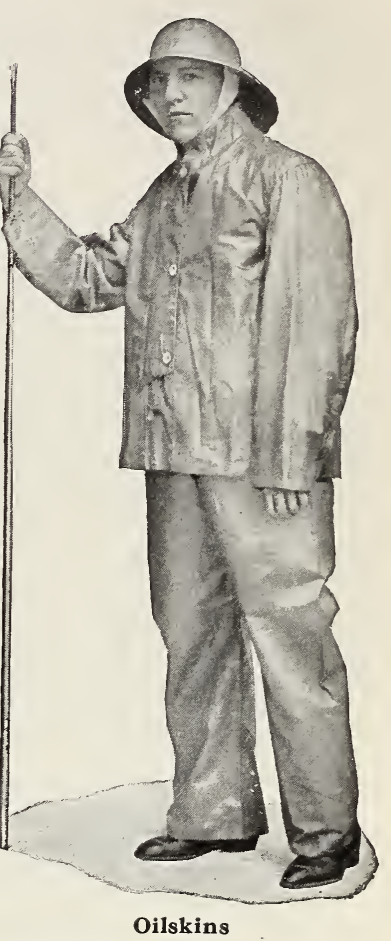

or use in spraying, pruning or garden work. $\$ 3.00$

Short $\$ 2.00$

\section{GOGGLES}

To protect the eyes when spraying. $\$ 1.25$ each.

\section{POMONA SPRAY PUMP}

The Pomona has sufficient capacity to supply two leads of hose and four nozzles. The plunger, plunger connection, gland, valves, valve seats and strainer are of solid bronze. All working parts are simple and so located that they can be easily removed and cleaned. The air chamber is of steel and has a large capacity, making it easy to maintain the pressure and giving smooth operation. The lever can be adjusted for a 3-, 4- or 5-in. stroke, the adjustment being obtained by removing and replacing a single bolt. The agitator is very simple but effective, and is operated by the pump lever.

Pump, with agitator and hose couplings............... $\$ 24.00$

Pump, with agitator and one lead of $15 \mathrm{ft} .1 / 2 \mathrm{in}$. discharge hose with spray nozzle................................ 300

Pump, with agitator and two leads of $1 / 2^{-i n}$. discharge hose with

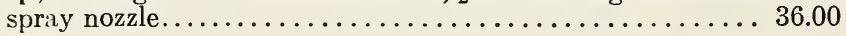
Either of the above mounted in barrel for $\$ 12.00$ extra.

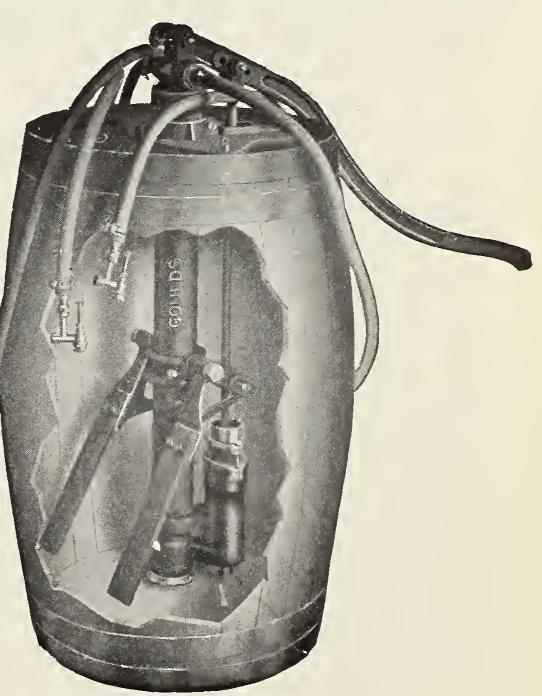

Pomona Spray Pump 


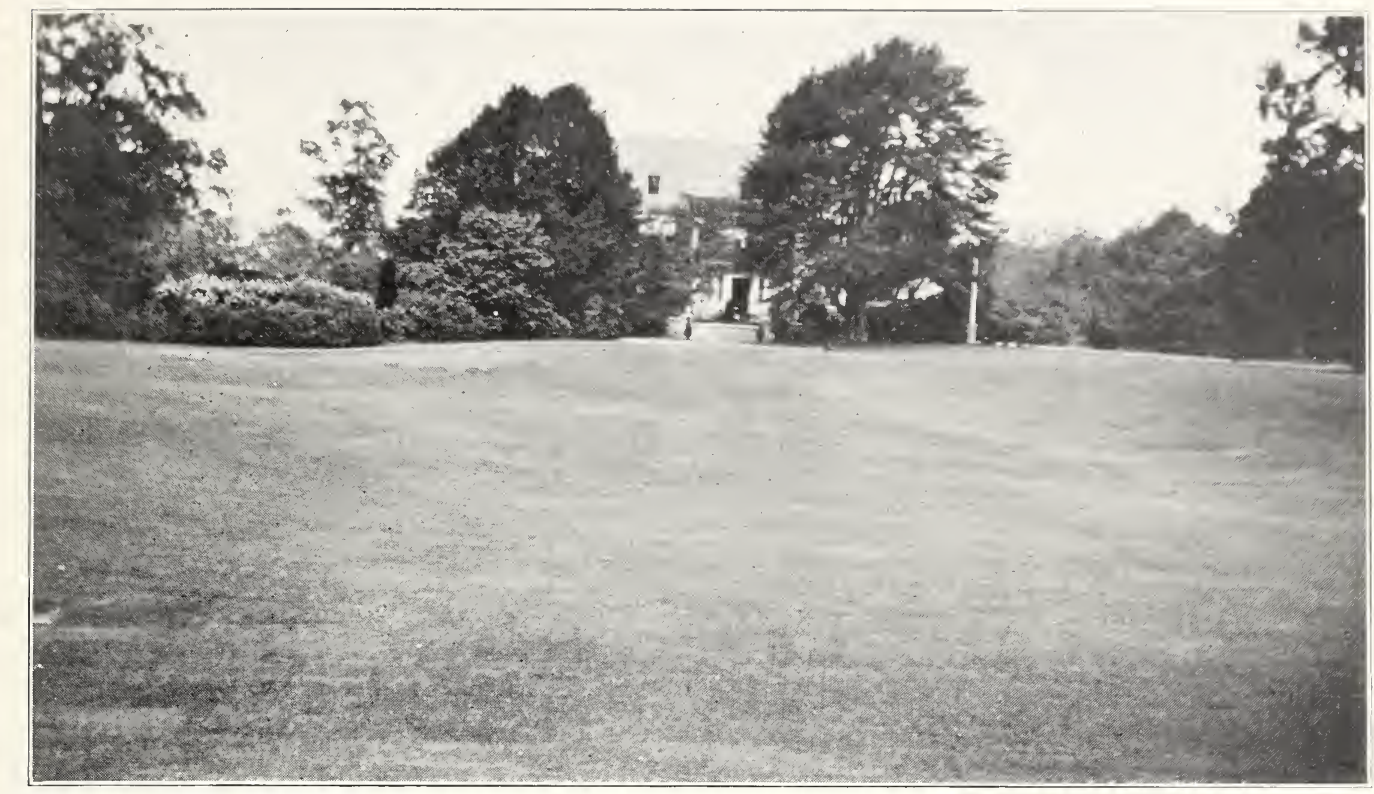

Part of Lawn at Mrs. R. G. Hazard Estate, Peace Dale, R. I., Thus. Houston, Supt., Lawn on Back Cover, Mrs. Paul Fitz-Simon, Newport, K. I., Wm. Judd, Supt.

\section{LAWNS}

The following simple directions may be found useful to those who are not familiar with lawn making:

The soil should be of good depth, moderately rich, and in many cases the land should be carefully drained. Grading should be done and the soil thoroughly pulverized by careful harrowing and raking. Some good fertilizerpure ground bone, wood ashes or a specially prepared lawn fertilizer-should be used. After spreading the fertilizer, the surface should be carefully raked and rolled. The rolling often develops uneven spots which should be leveled before the seed is sown. After sowing, the ground should again be lightly raked and rolled.

The selection of seed is important. Use only such mixtures as are free from weed seeds, and such as will produce a firm, strong turf and a fine growth. A liberal quantity is necessary to secure good results (not less than 64 lbs. per acre). The best time to make a lawn is from the middle of August through September. If seed is sown at this season, the grass will become strong enough to withstand the Winter, and a good lawn is assured the following season. If seed cannot be sown at this time, it should be sown as early as possible in the Spring.

Boston Lawn Grass Seed. This mixture is composed of such varieties as long experience has shown to be adapted to produce a permanent, heavy turf. Weighs $16 \mathrm{lbs}$. per bus. Lb. $45 \mathrm{c}$., $\$ 40.00$ per $100 \mathrm{lbs}$.

Grey's Special Recleaned Lawn Grass Seed. Recleaned seeds only are used in this mixture, and it is as free from weed seeds and chaff as the latest improved seed clenning machinery can make it, and it is composed of such varieties as make a close and lasting turf. In recommending this grade to our customers we are sure we are recommending a mixture which cannot be excelled for general lawn purposes. Weight 32 lbs. per bus. Sow 64 lbs. per acre. Lb. 65c., 100 lbs. $\$ 60.00$.

Mixture for Shaded Lawns. Fine grasses selected especially for locations partially shaded by buildings or trees. Weighs 24 lbs. per bus. Lb. 70c., 100 lbs. $\$ 65.00$.

\section{SPECIAL MIXTURES FOR TENNIS COURTS, GOLF LINKS, ETC.}

The following mixtures have been used on many prominent golf courses, etc., in this vicinity, and have given entire satisfaction.

Fair Green Mixture. For general use on golf links. Lb. 850 c., 100 lbs. $\$ 75.00$.

Putting Green Mixture. A combination of grasses best suited to produce a close, firm, and lasting turf, which will endure frequent cutting. Lb. $\$ 1.00,100 \mathrm{lbs}$. $\$ 90.00$.

Tennis Court Mixture. A mixture of fine grasses especially adapted to tennis courts, which will bear trampling without injury. Lb. 90c., 100 lbs. $\$ \$ 0.00$.

Ball Grounds Mixture. This mixture is used by both the leagues in Boston with the most satisfactory results. 32 lbs. per bus. Lb. 850 c., 100 lbs. $\$ 75.00$.

Bowling Green Mixture. A mixture of fine, hardy grasses, especially adapted for bowling greens. Lb. $\$ 1.00$, 100 lbs. $\$ 90.00$. 


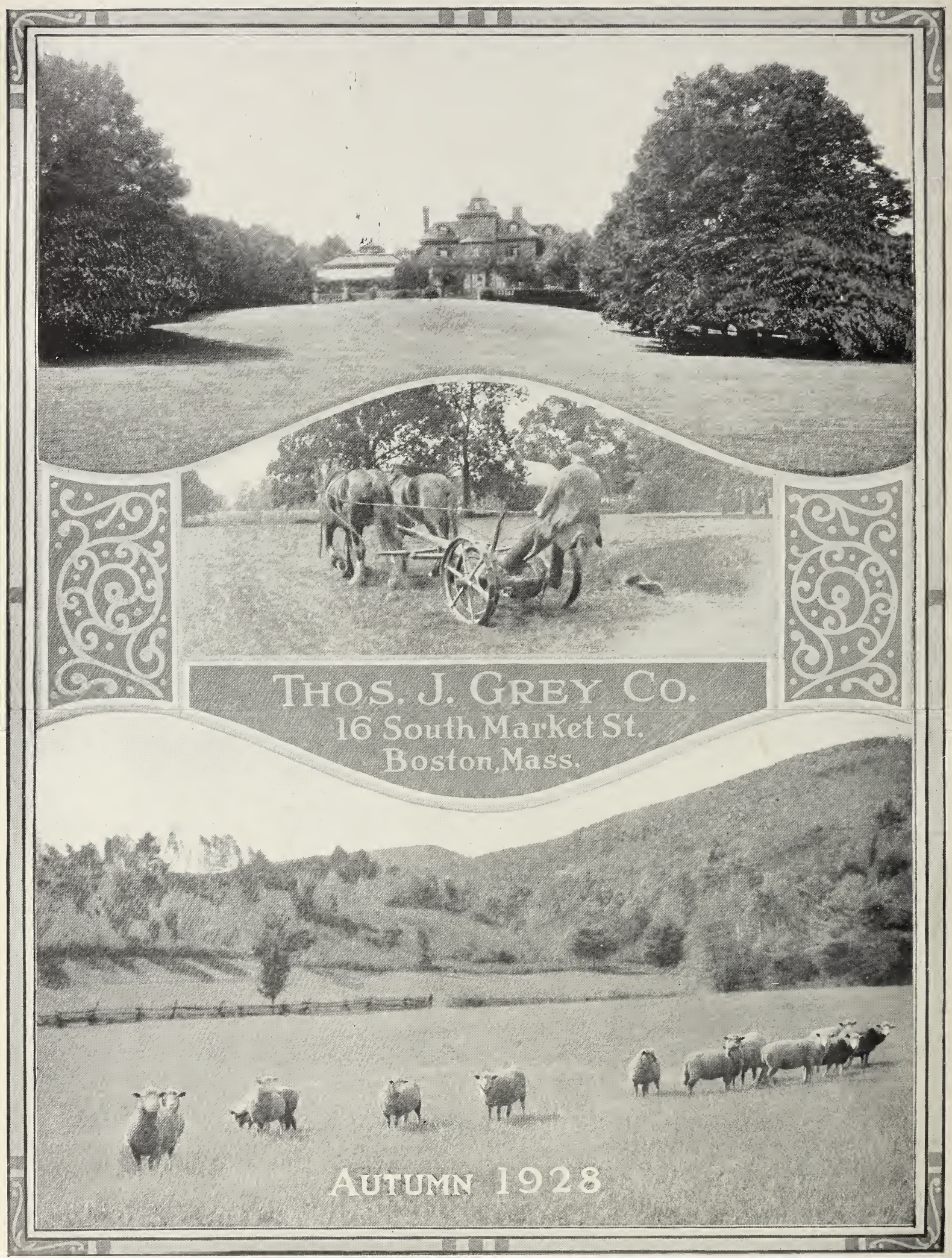

